\title{
Patulin in Apples and Apple-Based Food Products: The Burdens and the Mitigation Strategies
}

\author{
Lei Zhong ${ }^{1,2}$, Jason Carere ${ }^{2}$, Zhaoxin Lu ${ }^{1}$, Fengxia Lu ${ }^{1, *}$ and Ting Zhou ${ }^{2, *}$ \\ 1 College of Food Science and Technology, Nanjing Agricultural University, 1 Weigang, Xuanwu District, \\ Nanjing 210095, China; 2014208012@njau.edu.cn (L.Z.); fmb@njau.edu.cn (Z.L.) \\ 2 Guelph Research and Development Centre, Agriculture and Agri-Food Canada, 93 Stone Road West, \\ Guelph, ON N1G 5C9, Canada; jasoncarere@gmail.com \\ * Correspondence: lufengxia@njau.edu.cn (F.L.); ting.zhou@canada.ca (T.Z.); Tel.: +86-025-843-95693 (F.L.); \\ +1-226-217-8084 (T.Z.)
}

Received: 25 October 2018; Accepted: 9 November 2018; Published: 15 November 2018

\begin{abstract}
Apples and apple-based products are among the most popular foods around the world for their delightful flavors and health benefits. However, the commonly found mold, Penicillium expansum invades wounded apples, causing the blue mold decay and ensuing the production of patulin, a mycotoxin that negatively affects human health. Patulin contamination in apple products has been a worldwide problem without a satisfactory solution yet. A comprehensive understanding of the factors and challenges associated with patulin accumulation in apples is essential for finding such a solution. This review will discuss the effects of the pathogenicity of Penicillium species, quality traits of apple cultivars, and environmental conditions on the severity of apple blue mold and patulin contamination. Moreover, beyond the complicated interactions of the three aforementioned factors, patulin control is also challenged by the lack of reliable detection methods in food matrices, as well as unclear degradation mechanisms and limited knowledge about the toxicities of the metabolites resulting from the degradations. As apple-based products are mainly produced with stored apples, pre- and post-harvest strategies are equally important for patulin mitigation. Before storage, disease-resistance breeding, orchard-management, and elicitor(s) application help control the patulin level by improving the storage qualities of apples and lowering fruit rot severity. From storage to processing, patulin mitigation strategies could benefit from the optimization of apple storage conditions, the elimination of rotten apples, and the safe and effective detoxification or biodegradation of patulin.
\end{abstract}

Keywords: apples; apple-based products; patulin; blue mold; Penicillium expansum; detoxification

Key Contribution: This review summarizes the major factors and challenges affecting patulin contamination in apple products, and provides insights into the newly developed strategies, which could elevate patulin mitigation to a new pinnacle.

\section{Introduction}

The apple fruit (Malus sp., Rosaceae) is a nutrient-dense food, which is highly recommended to be included in healthy diets. With various phytochemicals and dietary fiber, apples contribute many health benefits to consumers, and participate in reducing chronic diseases [1,2]. According to the Food and Agriculture Organization (FAO), apples and apple-products (juices, purees, ciders, concentrates, and compotes) placed 17th in the list of the highest produced commodities worldwide [3]. The durability of a seasonal fruit, like apple, is largely affected by postharvest diseases. Approximately $25 \%$ and $50 \%$ of fruit product losses are caused by fungal pathogens during long term storage in 
developed countries and developing countries, respectively [4]. In terms of apples, the most common postharvest pathogen is Penicillium expansum, which may jeopardize the profitability of apple producers and negatively affect human health because of the blue mold decay and the consequent production of the toxic metabolite, patulin.

Patulin is viewed as a natural contaminant in apple-based products, particularly apple juice and unfermented apple cider. Initially identified as a broad-spectrum antimicrobial agent, patulin was reclassified as a mycotoxin in the 1960s because of its acute toxicity in human beings [5]. The amount of patulin in apple products was then considered as a measure of quality in regard to food safety standards/practices around the world. A provisional maximum tolerable daily intake of patulin has been set at $0.4 \mu \mathrm{g} / \mathrm{kg}$ body weight/day by the Joint FAO/WHO Expert Committee on Food Additives since 1995 [6]. Based on this, the maximum level of patulin has been restricted no more than $50 \mu \mathrm{g} / \mathrm{L}$ in apple juice and apple cider by the European Commission [7], the United States Food and Drug Administration [8], the Ministry of Health of the People's Republic of China [9], and Health Canada [10]. Solid apple products (e.g., apple sauce) and products for infants and young children have to meet tighter legislations, $25 \mu \mathrm{g} / \mathrm{kg}$ and $10 \mu \mathrm{g} / \mathrm{kg}$, respectively, as established by the European Commission [7]. The incidence of patulin contamination are a worldwide problem (Table 1), especially for the main producers of apples and apple-based products, such as China, the EU, and the USA [11]. An analysis of 35 apple products from Northeast China showed that $20 \%$ of these products have exceeded the current regulatory limit $(50 \mu \mathrm{g} / \mathrm{kg}$ ), the highest level of which has $94.7 \mu \mathrm{g} / \mathrm{kg}$ patulin in apple juice concentrate [12]. Another survey carried out analyzing 1987 apple juice concentrate samples from Shaanxi (2006-2010) indicated that $97.7 \%$ of the products were contaminated by patulin, ranging from 20.0 to $78.0 \mu \mathrm{g} / \mathrm{L}$ [13]. In Poland, $5 \mu \mathrm{g} / \mathrm{L}$ or more patulin was detected in $22 \%$ of the 754 apple juice samples collected during the 1993-2003 period [14]. In Italy, a report released in 2005 showed that the amount of patulin was $4.77 \mu \mathrm{g} / \mathrm{L}$ and $10.92 \mu \mathrm{g} / \mathrm{L}$ in conventional and organic apple juices, respectively [15]. In Michigan, USA, it was reported that $23 \%$ of apple-juice and cider samples from local groceries were contaminated by patulin, with concentrations ranging from 8.8 to $2700.4 \mu \mathrm{g} / \mathrm{L}$ [16]. Therefore, it is of great importance to investigate the mechanism(s) and causes of patulin incidence in apple products. 
Table 1. Occurrence of patulin contamination in apples and apple-based products reported in recent ten years (2008-2018).

\begin{tabular}{|c|c|c|c|c|c|c|}
\hline Type of Product & Country & Year of Samples & $\begin{array}{c}\text { Number of Samples } \\
\text { (Positive/Total Samples) }\end{array}$ & $\begin{array}{c}\text { Range } \\
(\mu \mathrm{g} / \mathrm{kg} \text { or } \mu \mathrm{g} / \mathrm{L})\end{array}$ & $\begin{array}{c}\text { Percentage of Samples } \\
\text { over } 50 \mu \mathrm{g} / \mathrm{L} \text { Patulin } \\
(10 \mu \mathrm{g} / \mathrm{L} \text { for Children's Food })\end{array}$ & Reference \\
\hline Apple & Pakistan (Punjab) & 2017 & $27 / 36$ & $<$ LOD-630.8 & $55.6 \%$ & [17] \\
\hline \multirow{11}{*}{$\begin{array}{l}\text { Apple juice (including } \\
\text { organic and conventional } \\
\text { apple juice and juice } \\
\text { concentrate) }\end{array}$} & China (Changchun) & 2009 & $\mathrm{ND} / 35$ & $<1.2-94.7$ & $20 \%$ & [12] \\
\hline & China (Shaanxi) & 2008-2010 & $568 / 574$ & $2.5-22.7$ & 0 & [13] \\
\hline & China (Hangzhou) & 2015 & $\mathrm{ND} / 4$ & $<$ LOD-16.8 & 0 & [18] \\
\hline & Portugal (Lisbon) & 2007-2009 & $28 / 68^{a}$ & $<$ LOD-42 & 0 & [19] \\
\hline & Spain (Navarra) & ND & $25 / 100$ & $<$ LOD-118.70 & $11 \%$ & [20] \\
\hline & Spain (Catalonia) & 2010-2011 & $21 / 47^{a}$ & $<$ LOD-36.5 & 0 & [21] \\
\hline & Serbia (Novi Sad) & 2013-2015 & $54 / 73$ & $<$ LOD-65.4 & $1.4 \%$ & [22] \\
\hline & Argentina & 2005-2013 & $1866 / 4634$ & $<$ LOD-19,622 & $0.8 \%$ & [23] \\
\hline & Pakistan (Punjab) & 2017 & $15 / 29$ & $<$ LOD-120.5 & $6.90 \%$ & {$[17]$} \\
\hline & Tunisia & 2011 & $11 / 30$ & 0-167 & ND & [24] \\
\hline & Malaysia & 2012-2013 & $1 / 13$ & $<$ LOD-26.9 & 0 & [25] \\
\hline \multirow{2}{*}{ Apple jam/marmalade } & China (Hangzhou) & 2015 & $\mathrm{ND} / 4$ & $<$ LOD-11.0 & 0 & [18] \\
\hline & Argentina & ND & $6 / 26$ & $17-39$ & ND & [26] \\
\hline \multirow{3}{*}{ Apple puree/apple pulp } & Argentina & ND & $4 / 8$ & $22-221$ & ND & [26] \\
\hline & Spain (Catalonia) & 2010-2011 & $6 / 46^{\mathrm{a}}$ & $<$ LOD-50.3 & $2.1 \%$ & [21] \\
\hline & China (Changchun) & 2009 & $\mathrm{ND} / 30$ & $<1.2-67.3$ & $36.7 \%$ & [12] \\
\hline \multirow{5}{*}{$\begin{array}{l}\text { Products for babies } \\
\text { (including apple juice, apple } \\
\text { sauce, and compotes) }\end{array}$} & Italy & 2008-2009 & $22 / 60$ & $3-9$ & 0 & [27] \\
\hline & Italy (Campania) & ND & $0 / 26$ & 0 & 0 & [28] \\
\hline & Tunisia & 2011 & $7 / 25$ & $0-165$ & $28 \%$ & [24] \\
\hline & Portugal (Lisbon) & 2007-2009 & $5 / 76$ & $<\mathrm{LOD}-5.7$ & 0 & [19] \\
\hline & Spain & 2008 & $0 / 17$ & 0 & 0 & [29] \\
\hline
\end{tabular}

$\mathrm{ND}$, not disclosed; LOD, limit of quantification; ${ }^{\mathrm{a}}$ infant drinks are included. 
Frequently found in the rotten tissues of apples, patulin accumulation correlates with apparent symptoms of blue mold. Apple blue mold usually starts with the invasion of P. expansum spores on the wounds of fresh apples. Such stem punctures, insect injuries, and bruises are created during the picking and handling operations in the apple orchard, until the final processing steps of products [30]. For over-ripening apples or apples that were held in storage for too long, open lenticels on the skin are also susceptible and can be easily attacked by the pathogen [31]. Furthermore, the colonization and germination of psychrophilic fungi, such as P. expansum, is barely affected by the lower temperature encountered in commercial storage rooms/facilities [32]. As lower-grade or unfit apples are usually used for juice or cider processing, the removal of rotten or damaged apples prior to pressing is strongly recommended by the FAO in order to reduce the occurrence of patulin in the final products [33]. However, even when decayed fruits are diligently culled, patulin has been constantly detected in apple products made from externally healthy apples that have internal rot which is not omitted before pressing. This invisible decay comes from the colonization of P. expansum in the opening calyx tube during apple blooming [30,34]. Once patulin is produced, conventional pasteurization only marginally reduces patulin in bottled apple juice [35]. In such cases, the development of strategies to effectively control patulin contamination in apple products during processing is of great importance.

Given the large consumption of apple products among infants and young children, the presence of patulin in apple-based products triggers concerns of food safety in the public. Moreover, the conventional control of blue mold decay by fungicides also concerns the public by itself, because of the potential risks of such chemicals to human health. In the view of blue mold and patulin, studies from the past decade have reviewed patulin-producing strains and their biosynthesis genes [36,37]. Considering that patulin is often detected in apples products, factors that affect patulin production in apple fruits, conventional practices for postharvest control, and the fate of patulin during juice processing have been discussed [32,38-40]. In fact, the severity of blue mold is directly associated with the amount of patulin produced in apples, and the later further makes P. expansum more aggressive during long time storage [41]. Practices like pasteurization can only eliminate the existence of the pathogen, but not the presence of patulin [35]. Therefore, this review will discuss the factors and challenges that affect patulin production and its removal from apples, as well as the emerging strategies in reducing pathogen infection and patulin contamination in apples from orchards to dining tables, with a focus on the work published in the last decade, with an aim of highlighting future prospective.

\section{The Burdens of Patulin Accumulation in Apples and Apple Products}

The high level of patulin contamination in apple products continues to be a problem because of the complicated factors that are associated with patulin production, as well as the challenges that hamper the control of patulin levels in apple products.

\subsection{Factors Affecting Patulin Production in Apples}

A sufficient pathogen load, susceptible apple cultivars, and favorable environments are the fundamental elements required for the occurrence of any plant disease [42]. Widely spread in storage rooms, P. expansum is the most important causative agent of blue mold decay and patulin producer in apples. Among the thousands of apple cultivars, some of them show a fast response toward wounding and decaying, while other susceptible ones fail to combat pathogen attack, resulting in a large accumulation of patulin within the fruit's flesh.

\subsubsection{Toxigenic Penicillium Species}

Patulin production is often detected within the decayed area, which is majorly caused, by P. expansum and other pathogenic Penicillium. In a recent study, among the 166 fungal isolates that have been reported to produce patulin, 77 belong to pathogenic Penicillium [37]. As a psychrophilic fungus, $P$. expansum grows well at $0{ }^{\circ} \mathrm{C}$ or even $-2 /-3{ }^{\circ} \mathrm{C}$, so infection can still take place during the cold storage of apples [43]. Moreover, the population of Penicillium is usually higher within 
storage facilities than that in the fields. In a French apple orchard, the density of Penicillium was less than 50 spores $/ \mathrm{m}^{3}$, however, 2500 spores $/ \mathrm{m}^{3}$ of Penicillium were detected in the atmosphere of previously disinfected warehouses, where P. expansum and Penicillium solitum accounted for 20.0-65.6\% and $6.0-47.1 \%$, respectively [31]. An isolation of the fungal species in long-term stored "Jonagold" apples in Belgium also indicated that P. expansum and P. solitum were the dominating species [44]. Although P. solitum is unable to produce patulin, it acts as a predisposing agent, which allows the entry of $P$. expansum and causes more destructive infections [37,45]. Moreover, the average population of Penicillium on the surface of stored apples was $10-50$ spores $/ \mathrm{cm}^{2}$ in the first month, and went up to 300-400 spores $/ \mathrm{cm}^{2}$ after the sixth month [31]. While sound apples are unlikely to become infected by the pathogen [46,47], the apples that are exposed to high concentration of Penicillium spores could develop severe decay after long-term storage.

Patulin accumulation in apples is affected by the severity of blue mold and the toxin-producing capacity of $P$. expansum. Generally, the severity of the rotten tissue is positively correlated with the patulin content in apples [48]. However, the role of accumulated patulin in the aggravation of blue mold decay in apples has not been fully elucidated in the existing literature yet [49]. A wide range of P. expansum strains have recently been reported to produce patulin with a production capacity that is varies from strain to strain. The highest production level of patulin by P. expansum isolates from Vineland, Woodstock, and Georgian Bay in Ontario, Canada, was around $0.66 \mathrm{mg} / \mathrm{kg}$ [50]. While the P. expansum isolate FC116 from Belgian “Jonagold" apple orchards was able to produce $747 \mathrm{mg} / \mathrm{kg}$ patulin in vitro [44]. More intriguing, there was no correlation between patulin accumulation in actual apples and in the potato dextrose agar, even by the same P. expansum isolate [51]. In addition to the noticed differences at the genetic level between patulin producing P. expansum strains, apple cultivars and environmental conditions also play important roles in disease severity and patulin accumulation.

\subsubsection{Traits of Apple Fruits}

In nature, patulin is more likely found in apples and apple products, because the physicochemical properties of apple fruits are suitable for P. expansum growth. With water activity $\left(a_{\mathrm{w}}\right)$ at $0.98-0.99$, apple fruits meet the minimal level of $a_{\mathrm{w}}$ for P. expansum spore germination and patulin biosynthesis, which are around $0.83-0.85$ and 0.99 , respectively [52]. The $\mathrm{pH}$ range of the apple $(=3.1-4.2)$ also satisfies P. expansum colonization and patulin production ( $\mathrm{pH} 2.5-6)[53,54]$. Other than these two factors, different genetic backgrounds and growth conditions shape the physical and chemical traits of apple fruits, which eventually determine the wound healing ability, as well as the susceptibility to blue mold and patulin production in wild or cultivated apples.

The defense system of injured apples, whether resistant or susceptible to P. expansum attacks, is highly regulated by specific genetic information. Apple cultivars that share close genetic profiles show a similar response to pathogen attack. When inoculated with same amount of P. expansum spore suspension, a similar growth pattern of P. expansum was observed on "Golden Delicious" and its descendants "Pink Lady" and "Ariane" apples [55]. Collected from Central Asia (mainly Kazakhstan), the accessions of a wild apple cultivar Malus sieversii showed resistant behavior to P. expansum infection, and most of the studied cultivars were able to survive the inoculation of P. expansum at $1 \times 10^{3} \sim 1 \times 10^{4}$ spores/mL [56]. The immune accession GMAL 4317.f can even survive the inoculation at $10^{5}$ spores $/ \mathrm{mL}$ [57]. To resistant apples, the better basal defense and faster stress response are the result of differential genes expression, including the genes that encode wound-healing or defense-related proteins, as well as reactive oxygen species (ROS) detoxifying enzymes in response to patulin [58]. The latest identification of the qM-Pe3.1 quantitative trait loci (QTL) in M. sieversii attributes the fundamental reason of susceptible apples is the lack of a peculiar allele that controls blue mold resistance [59]. Beyond the intrinsically genetic strength, the transcriptomic analysis also revealed that the resistant $M$. sieversii had a much more rapid wound-healing behavior than that in the susceptible "Royal Gala" [60]. A similar pattern has also been used to explain the difference of decay incidences among immune, resistant, and moderately resistant $M$. sieversii accessions [61]. 
It is unfortunate that the patulin content was not evaluated in the abovementioned research. It is most likely that a reduced decay area would in turn translate to reduced levels of patulin in the fruit, even though the patulin accumulation may not be positively correlated with disease severity in all of the studied cases.

Flesh firmness is an important sensory trait of all apple cultivars, particularly domesticated ones, that is associated with the fruit's resistance to blue mold decay and patulin production. With fruit ripening, the flesh texture becomes softer, which leads to higher risks of pathogen infection [62]. Generally, a negative correlation between the firmness and severity of blue mold in apples has been reported widely. Caused by P. expansum, the decay incidences were incredibly high in over-ripe "Golden Smoothee" apples, because of decreased flesh firmness [63]. A similar phenomenon has also been discovered in a total of 28 apple genotypes from Mexico, where the commercially ripe apples showed less susceptibility to P. expansum than the over-ripe apples [64]. With poor firmness, rots were developed in over-ripe apples even by non-host pathogen Penicillium digitatum [63]. However, the relationship of fruit firmness and disease tolerance differs among early- and late-ripening cultivars. After storage for 6-12 weeks, a negative correlation between the fruit firmness with the lesion diameter of blue mold decay was only found in the late-ripening, but not in the early-ripening cultivars [65]. It has been confirmed that an increased level of patulin in apples positively correlates to the decreased firmness of fruits [66]. Beyond firmness, traits like fruit size, skin color, peel thickness, and cuticular wax, also act as implicit factors affecting the tolerance level of the cultivar to the invading pathogen and patulin production $[64,67]$. Mainly inherited ancestrally, these physical traits are also affected by sun exposure and the ethylene level, which has a strong connection with the surrounding environmental conditions and chemical constitution.

The apple fruit contains a wide range of chemicals, which significantly affect host resistance to fungal diseases. The most important chemical constituents that are associated with patulin accumulation in apples are the levels of ethylene, polyphenols, and sugars.

Known as a major hormone in regulating fruit ripening and softening, ethylene also plays a role in the apple's defense against pathogen infection. A lower ethylene production rate has been recognized as the major reason of a greater resistance to blue mold decay in late-ripening cultivars [68]. Moreover, the endogenous production of ethylene can be used as an indicator of wound healing in apples [69]. During P. expansum invasion, the ethylene production and ethylene-mediated wound response mechanisms were suppressed in apples, which in turn made pathogen colonization much more easier [70]. Therefore, faster wound healing results in less decay and less accumulation of patulin in apples.

Similarly, many abundant polyphenols in apples are also involved in the response to patulin attack through scavenging the free radicals induced by patulin. A study of 24 apple cultivars revealed that flavonols and procyanidins B2 from apple peel and flesh played a significant role in blue mold resistance [71]. Higher concentration of epi-catechin and procyanidin B1 were also found in resistant M. sieversii PI 369855, in comparison to susceptible "Golden Delicious" (M. domestica) [57]. Both observations supported the possibilities of phenolic compounds to positively contribute-at the basal level一to the resistance of $P$. expansum attacks in apples.

Another key component of apple fruit that modulates the accumulation of patulin is sugars, particularly sucrose. The addition of glucose, sucrose, or maltose at a final concentration of $10 \mathrm{~g} / \mathrm{L}$ (about $29.2 \mathrm{mM}$ ) to a basal medium (without a carbon source), led to the highest yields of patulin by P. expansum strains T01, M1, and Pe21. [54]. However, a decrease of patulin production by P. expansum isolates T01 and Pe21 was observed in a solid secondary medium, where the sucrose concentration ranged from 15 to $175 \mathrm{mM}$ [41,72]. The differences in the amount of sucrose within these two culture media could be the reason behind the variations in patulin accumulations. As sucrose makes up the large part of sugars in apple fruits, the changes of sucrose content during fruit ripening may be associated with fungal metabolism and mycotoxin synthesis. 


\subsubsection{Environmental Conditions}

During apple planting, factors like annual precipitations can directly affect apple yield and quality, from aroma and flavor to flesh firmness, even disease resistance. Heavy precipitations in Hungry and Queretaro led to severe blue mold decays in apples during 2010 and 2011, respectively [64,73]. However, these seasonal factors are unpredictable. Fresh apples continue respiring even after they are harvested. Generally, harvested apples are stored either in air $\left(10-25^{\circ} \mathrm{C}\right)$ for 3-4 months, or in cold, hypoxic conditions $\left(0-4{ }^{\circ} \mathrm{C}, 1-3 \% \mathrm{O}_{2}\right.$, and $\left.0.03-5.00 \% \mathrm{CO}_{2}\right)$ for up to 12 months $[74,75]$. Environmental changes such as temperature, gas composition, and $\mathrm{pH}$, could affect patulin accumulation by regulating the traits of the apple and the physiological properties of P. expansum, like the ability to produce patulin.

The temperature at storage facilities has an effect on the development of blue mold decay, which directly associates with patulin production in rotten apples. More importantly, the patulin from these rotten apples is likely to pass to the final products if processing fails to remove the mycotoxin.

Ambient temperature has a crucial effect on the growth and colonial morphology of P. expansum, thus the production of secondary metabolites such as patulin in apples could also be affected [76]. Although P. expansum can grow well at $0{ }^{\circ} \mathrm{C}$ or below, a faster sporulation and mycelia growth have been observed when the storage temperature set at $20-25{ }^{\circ} \mathrm{C}[52,53,77,78]$. The effect of storage temperature on patulin production is more complicated. The highest amount of patulin was found in "Red Delicious", "Golden Supreme", “Gala", "Fuji", "Empire", and "McIntosh", as well as in apple cider samples, when the storage temperature set above $20^{\circ} \mathrm{C}[50,79]$. However, higher levels of patulin were also been observed when "Red Chief" apples and apple sauce were stored at $1{ }^{\circ} \mathrm{C}$ or $4{ }^{\circ} \mathrm{C}$ instead of $22{ }^{\circ} \mathrm{C}$ or $23^{\circ} \mathrm{C}$ [80]. P. expansum isolates exhibited varying abilities of patulin production when incubated at $1{ }^{\circ} \mathrm{C}$ or $20^{\circ} \mathrm{C}$, suggesting a strain specificity in stress conditions [81]. Considering the enormous diversity of $P$. expansum isolates and apple cultivars, it is necessary to investigate in the future how the interactions of pathogen strains and apple cultivars can affect patulin production.

In juice manufacturing, apples are first sent to pre-treatment, like washing and selection; then pressing and juice holding; followed by juice filtration; and finally, sterilization and bottling [39]. Pasteurization, evaporation, and distillation are the common preservation methods, which are expected to remove the detrimental microorganisms and even mycotoxins. However, the effect of heat treatments on patulin is still controversial, probably due to the differences in the initial concentration of patulin in apple products [40]. A significant reduction of patulin from apple products was only observed in early attempts. Approximately $90 \%$ of the original $100-150 \mu \mathrm{g} / \mathrm{mL}$ patulin was removed after $29 \mathrm{~h}$ heating at $105^{\circ} \mathrm{C}$ [82]. Considering the nutrient loss and the low organoleptic properties after a high temperature treatment for a prolonged time, a high-temperature short-time sterilization is more widespread for processed apple products. However, limited effectiveness has been reported with regard to patulin removal. When apple juice was pasteurized for $30 \mathrm{~s}$ at $90^{\circ} \mathrm{C}$, the level of patulin was reduced from $433 \mu \mathrm{g} / \mathrm{L}$ to $262 \mu \mathrm{g} / \mathrm{L}$, which was a $39.6 \%$ reduction [83]. In another trial of apple puree, a $20.7 \%$ decrease of the initial $140 \mu \mathrm{g} / \mathrm{L}$ patulin were monitored when the products were heated at $90{ }^{\circ} \mathrm{C}$ for $10 \mathrm{~min}$ or $30 \mathrm{~min}$, respectively [84]. As patulin is thermally stable in an acidic condition, the natural $\mathrm{pH}$ of apple juice could help stabilize the patulin and reduce the effectiveness of any heat treatment.

The composition of gas, particularly $\mathrm{O}_{2}$ and $\mathrm{CO}_{2}$ in the storage room, has crucial influence on apple ripening and patulin production by P. expansum. In general, apples are usually picked during the pre-climacteric stage (unripening) or climacteric stage (commercial ripe), and are sent to storage rooms with a controlled atmosphere, which could help slow down the apple ripening and prolong the shelf-life to supply fresh fruit throughout the year [85]. Not only related to apple ripening, the adjustment of gas composition also affects the flesh firmness of the apple, which plays a role in response to pathogen attack and patulin production. However, the growth of $P$. expansum is not affected by lower $\mathrm{O}_{2}$ or higher $\mathrm{CO}_{2}$ [32], and the effect of limited oxygen on patulin accumulation in apples is debatable. In a model of apple puree agar media, the effect of reducing the $\mathrm{O}_{2}$ level from $20 \%$ to $3 \%$ on patulin production by P. expansum was strain-dependent; while a consistent suppression of patulin production was observed in all of the tested P. expansum strains when the $\mathrm{O}_{2}$ was dropped 
from $3 \%$ to $1 \%$ [86]. In different stages of apple storage, no significant variation of the patulin content was observed, although the content of oxygen changed significantly [44]. Similarly, limited $\mathrm{O}_{2}$ storage failed to reduce patulin in the "Galaxy" and "Fuji Kiku" apples from Brazil [46]. These results indicated that the effect of a controlled atmosphere on patulin reduction is a complicated process, which is not only affected by apple cultivars and P. expansum strains, but is also affected by abiotic stresses like the temperature of the storage room, the material of the apple package, and the pre-treatment of apples before the storage.

Changes in the environment $\mathrm{pH}$ have less to do with the traits of the harvested apples, but more to do with the physiology and pathogenicity of P. expansum, which further determine the production of patulin in apples. Patulin accumulation as well as the spore germination and biomass formation of P. expansum can benefit from a lower $\mathrm{pH}$ condition (pH 3-5) in apples $[54,87]$. During P. expansum infection, two $\mathrm{pH}$-modulators, D-gluconic acid and ammonia, are secreted and act as the precursors for patulin biosynthesis process [41]. The former acidifies the apple tissues and enhances the colonization of $P$. expansum by activating the cell wall degrading enzyme polygalacturonases [88]. With the sequential consumption of sugars and D-gluconic acid as the carbon source for pathogen growth, ammonium accumulates in apples and then contributes to patulin production by inducing the expression of a $\mathrm{pH}$ modulator, PacC [41].

\subsection{Challenges in the Control of Patulin Levels in Apple Products}

Patulin accumulation in apple fruits is a complicated process that is deeply affected by the abovementioned factors, like Penicillium, apple fruits, and environment. The cross-linked interactions between such factors block the development of the effective control measures of blue mold decay, hence, patulin production in apples. Moreover, the control of patulin levels in food is also challenged by the difficulties in the rapid detection of patulin residues in food matrixes.

Among all of the developed strategies to reduce blue mold decay and detoxify patulin in apple products, antagonist microorganisms showed superior advantages were hence recognized as promising biological control agents in the fruit industry. However, their safe usage is under scrutiny because of the unspecific degrading mechanism(s), as well as the incomplete toxicological assessment of degradation by-products or derivatives.

\subsubsection{Difficulties of Patulin Detection in Apple Products}

Reliable and sensitive assays for detecting patulin within different food matrixes is the primary requirement in managing patulin contaminations. However, the complicated composition of apple products could cause a deviation in the identification and quantification of patulin by compounds that share a similar chromatographic behavior to patulin.

For many years, the most widely used strategy to detect patulin was solvent extraction, followed by a clean-up step, and finally, chromatographic analysis using a reverse phase HPLC coupled with ultra-violet (HPLC-UV) detection at $277 \mathrm{~nm}$ [89]. Although HPLC-UV shows good repeatability and high quantitative precision, this method is undermined because of the presence of interfering substances from apple or apple by-products formed during processing [90,91]. Among them, 5-hydroxymethylfurfural (5-HMF), pectin, and some proteins have been found in liquid and dried apple products that interfere patulin determination [18,92]. During heat pasteurization, $5-\mathrm{HMF}$ is formed as a dehydration product of fructose in acidic conditions [93]. As both 5-HMF and patulin have a maximum UV absorption at $276 \mathrm{~nm}$, the appearance of 5-HMF could affect the accuracy of quantifying patulin in foodstuffs [25]. Likewise, pectin with its high abundance is also regarded as an interferer when the extraction and chromatographic separate of patulin from apple products is conducted [94]. Although the inclusion of an enzymatic hydrolysis step is a commonly practiced depectinization approach, such a treatment can result in a significant under estimation of patulin and lower recovery rates of patulin due to the formed pectin hydrolysate [95]. Moreover, an interaction 
of patulin and approximately $20 \%$ proteins occurred in cloudy apple juice, where bound patulin was formed and was difficult to extract using organic solvents [96].

Although liquid chromatography-mass spectrometry (LC-MS) has powerful capabilities in separation and identification, this method is challenged by the physicochemical properties of patulin. As a hydrophilic and high polar polyketide, patulin has a 154.0266 Da monoisotopic molecular mass, which is consistent with 13 fungal secondary metabolites, including intermediates from patulin biosynthesis pathways like neopatulin (or isopatulin) [37]. Sharing the same functional groups, neopatulin is an optically inactive isomer, which is difficult to be distinguished by MS [97]. The poor ionization of patulin, not matter in electrospray or in atmospheric pressure chemical ionization conditions, makes it frequently omitted when monitoring multi-mycotoxin in foodstuffs [98]. The high expense of instrumentation is probably another impediment that hinders the promotion of the LC-MS-based detection of patulin in apple products.

\subsubsection{Insufficient Toxicological Assessments of Patulin and Its Breakdown Products}

As the only regulated small toxic lactone, the permitted level of patulin in apple-based foods for children, infants, and babies is lower than that for adults [37]. Young children are at greater risk of intoxication because of their specific dietary pattern, low body weight, higher metabolic rate, and poor ability to detoxify hazardous xenobiotics [99]. Therefore, toxic assessments of patulin and its related metabolites should be studied comprehensively. Up until recently, the toxic effects of patulin have been explored in vivo [100], ex vivo [101], and in vitro [102] (Table 2). Long-term exposure to patulin is accompanied with genotoxicity, cytotoxicity, immunotoxicity, neurotoxicity, and severe damage to mammalian organs, especially kidneys and livers [103,104]. Although the long term exposure of rats and mice indicated the potential carcinogenicity of patulin, the International agency for Research on Cancer (IARC) classified patulin in group 3, "not classifiable as a carcinogen to humans" because of insufficient evidence [104]. 
Table 2. Structure and producer of patulin and degradation products.

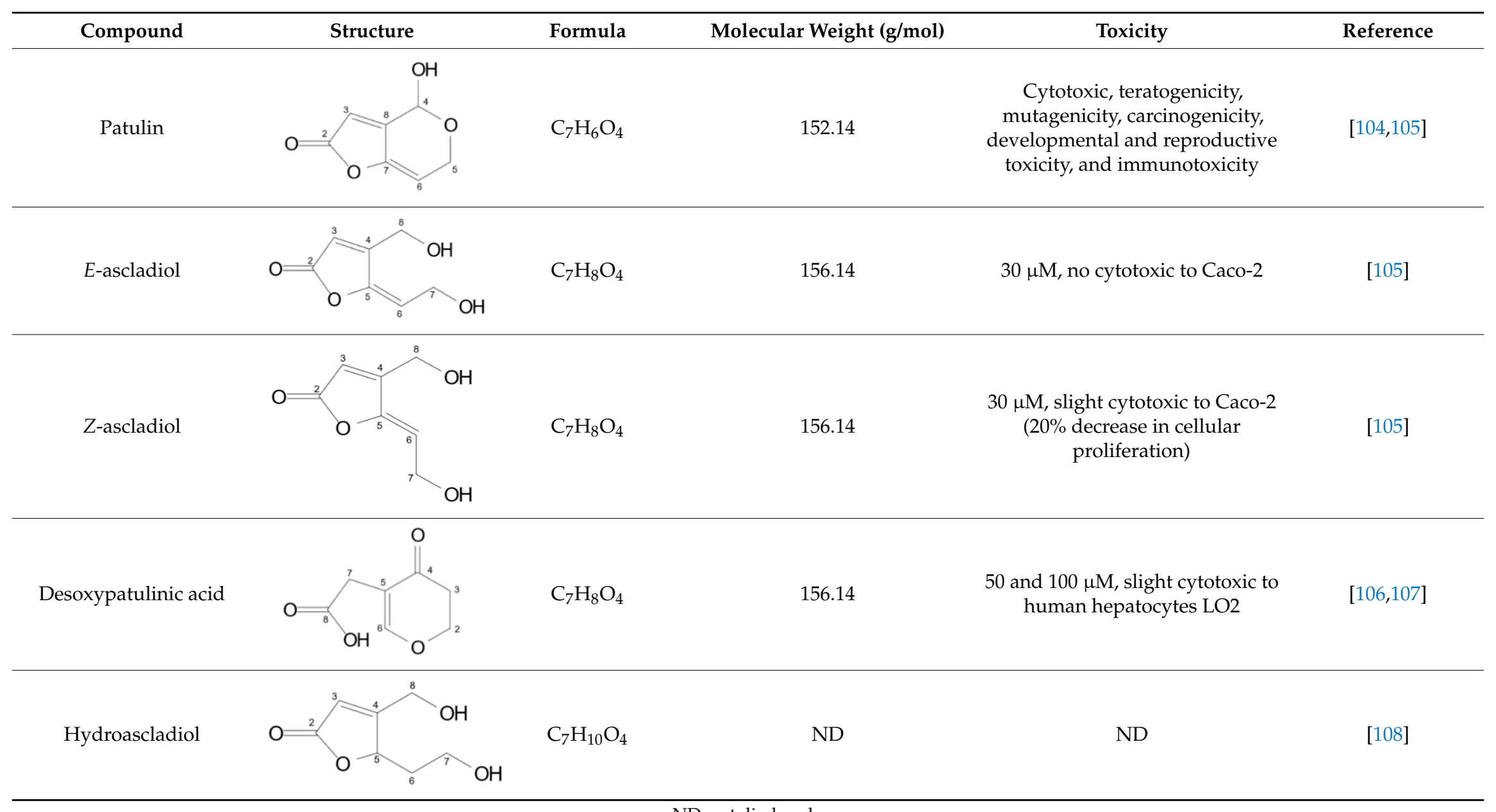


Compared to patulin, the toxicology of patulin-related metabolites is less investigated, which include degradation products (mainly produced by biocontrol microorganisms) (Table 2) and conjugates (mainly produced by patulin and thiol-contained compounds). Three patulin degradation products have been widely reported, which are desoxypatulinic acid and two isomers of ascladiol (E- and Z-ascladiol) $[89,109]$. With opened pyran rings, these breakdown products showed less cytotoxicity to human cell lines than patulin $[105,107]$, but no further reports on their carcinogenicity, genotoxicity, or other toxic effects. The newly found hydroascladiol was produced after the four-week incubation of the first degradation product ascladiol with Lactobacillus plantarum [108], for which the toxicity is still largely unknown. Patulin conjugates are produced because of its electrophilic attack to sulfhydryl groups of nucleophiles, such as cysteine and methionine, from live cells $[110,111]$. The cysteine-containing tripeptide glutathione (GSH; $\gamma$-Glu-Cys-Gly) could also become the target to patulin [112]. Although patulin/cysteine conjugates are considered less or nontoxic to intestinal cell lines, the toxicological profiles of 22 (or more) mass spectra identified patulin-GSH adducts remain elusive [112-114]. As GSH is a scavenger of free radical and the cofactor for various antioxidant enzymes, its role in patulin detoxification needs further investigation.

\subsubsection{Unspecific Mechanisms of Patulin Degradation by Microorganisms}

In recent years, the use of antagonistic microbial agents to control postharvest blue mold decay and reduce patulin accumulation in apple products has shown great potential [36]. Some protein (e.g., phosphomannomutase) and polysaccharides from the yeast cell wall could bind patulin $[115,116]$. As patulin causes the generation of reactive oxygen species (ROS), it is highly possible that antioxidant genes/proteins are responsible for patulin detoxification in cells. However, few reports have disclosed the degrading genes/enzymes involved in the biodegradation pathways. A DNA microarray assisted transcriptome analysis found that the genes involved in the proteasome, sulfur amino acid metabolism, and oxidative stress of Saccharomyces cerevisiae were highly induced by patulin [117]. The deletion of superoxide dismutase encoding gene SOD1 elevated yeast susceptibility to patulin attack [118]. In Schizosaccharomyces pombe, the expression of the $\mathrm{Cu} / \mathrm{Zn}$ superoxide dismutase, catalase, and glutathione S-transferase were increased as a consequence of the activated transcription factor Pap1 by patulin [119]. Moreover, a collection of 3000 T-DNA inserts helped to identify four homologous genes of S. cerevisiae, YCK2, PAC2, DAL5, and VPS8, in Sporobolomyces sp. IAM13481 were sensitive to patulin treatment [120]. A more recent proteomic profiling revealed that both the abundance of protein U7 (a short-chain dehydrogenase) and the expression of its coding gene were significantly increased by patulin treatment, which suggested the possibility of this protein's involvement in patulin degradation in Candida guilliermondii [121]. As none of these genes have their function validated in vitro, more work needs to be done to prove that patulin degradation is performed through specific enzymes/pathways.

\section{Strategies for the Mitigation of Patulin Contamination in Fresh Apples and Processed Products}

During the past few decades, researchers have been dedicated to exploring strategies to reduce patulin contamination in apple products. The Ontario Ministry of Agriculture, Food, and Rural Affairs (OMAFRA) summarized the indicators of higher level of patulin, including the fallen apples, visibly rotten or bruised apples, and apples from atmospherically stored conditions [122]. The most common and effective methods to control patulin level are also listed, which consist of the regular inspection and removal of decayed apple prior to processing. However, the culling of rotten apples will not be as efficient, unless the decayed areas are on the surface and visible. Other strategies are also developed aiming at the control of apple blue mold. Among which, the application of fungicides (e.g., thiabendazole) had already been used to reduce disease incidents [123]. Fungicides with potential risks of chemical residue carryovers and the development of fungicide-resistant species have caused worry among the public, and therefore, have been gradually banned in most countries [124,125]. Considering the fate of apples from orchard to table (Figure 1), green and effective strategies that 
inhibit apple blue mold and control patulin levels in apple-based products will be discussed in this section.

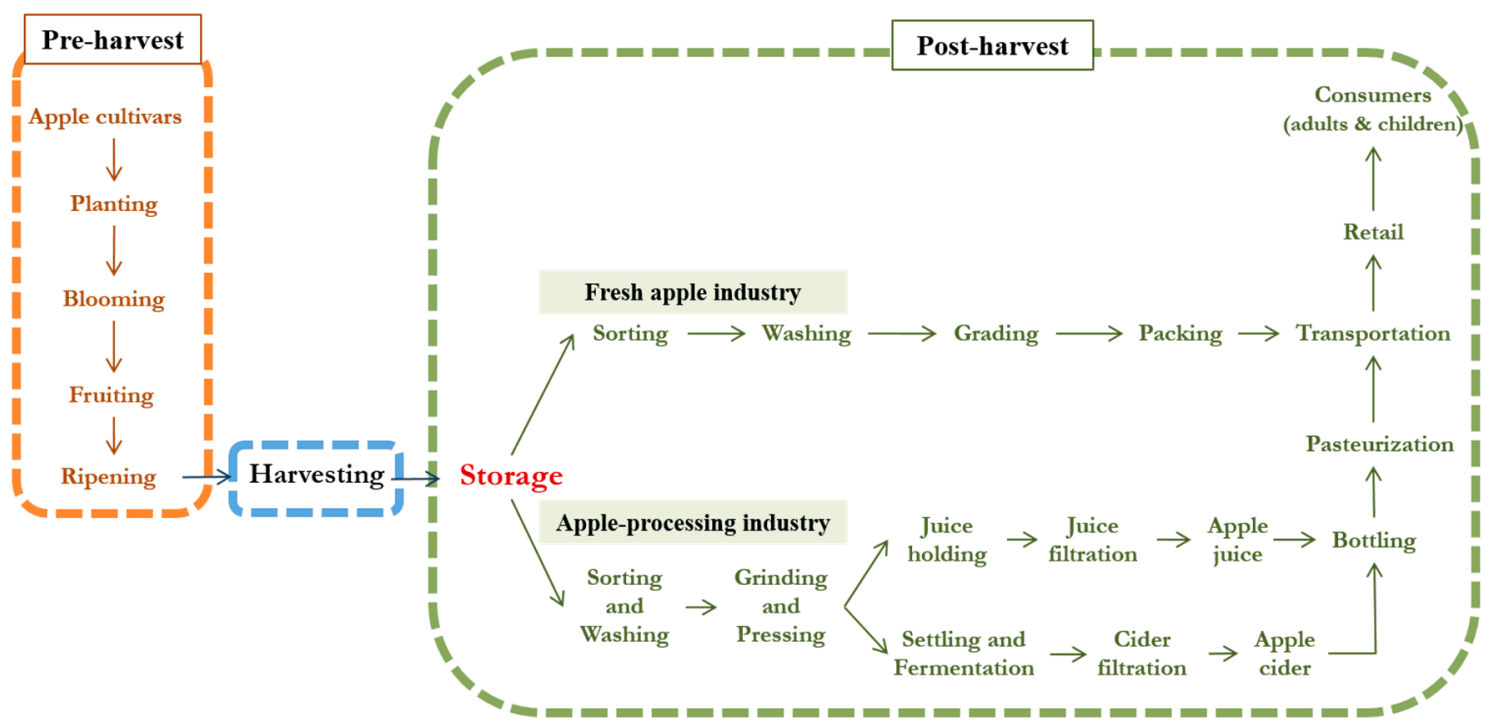

Figure 1. Flowchart of apple from orchard to processing.

\subsection{Preharvest Control of Blue Mold to Reduce Patulin Accumulation in Apples}

Slow-healing wounds and poor resistance against P. expansum are two major reasons for patulin accumulation in apples. To achieve the goal of having less patulin in apples and apple products, the preharvest prevention should focus on increasing disease resistance in apples, and the reduction of blue mold incidence and severity in apples, via lowering the spore population and growth rate of P. expansum (Table 3 ). 
Table 3. Newly developed strategies for blue mold control and patulin mitigation in apples and apple products.

\begin{tabular}{|c|c|c|c|c|c|c|c|c|c|}
\hline \multirow{2}{*}{ Category } & \multirow{2}{*}{ Method } & \multirow{2}{*}{ Description } & \multirow{2}{*}{$\begin{array}{c}\text { Type of } \\
\text { Apple Products }\end{array}$} & \multirow{2}{*}{$\begin{array}{c}\text { P. expansum Spore } \\
\text { Suspension (spores } / \mathrm{mL} \text { ) }\end{array}$} & \multicolumn{2}{|c|}{ Blue Mold Decay Incidence } & \multicolumn{2}{|c|}{ Patulin Content } & \multirow[t]{2}{*}{ Reference } \\
\hline & & & & & Control & Treatment & Control & Treatment & \\
\hline \multirow{4}{*}{ Orchard } & \multirow{4}{*}{ Spray elicitor } & & McIntosh apple & \multirow{3}{*}{$5 \times 10^{3}$} & $70 \%$ & $30 \%$ & ND & ND & \multirow{3}{*}{ [126] } \\
\hline & & Harpin $(80 \mathrm{mg} / \mathrm{L})$ & Empire apple & & $32 \%$ & $5-10 \%$ & ND & ND & \\
\hline & & & $\begin{array}{c}\text { Red } \\
\text { Delicious apple }\end{array}$ & & $30 \%$ & $4 \%$ & ND & ND & \\
\hline & & Ammonium molybdate (1 mM) & $\begin{array}{c}\text { Golden } \\
\text { Delicious apple }\end{array}$ & $1 \times 10^{4}$ & $49 \%$ & $35 \%$ & ND & ND & [127] \\
\hline \multirow{11}{*}{$\begin{array}{l}\text { Before } \\
\text { P. expansum } \\
\text { inoculation }\end{array}$} & \multirow[b]{2}{*}{$\begin{array}{l}\text { Heat } \\
\text { treatment }\end{array}$} & $\begin{array}{l}\text { Hot water dipping } \\
\left(45^{\circ} \mathrm{C}, 10 \mathrm{~min}\right)\end{array}$ & Ultima Gala apple & $1 \times 10^{4}$ & $>80 \%$ & $0 \%$ & ND & ND & [128] \\
\hline & & $\begin{array}{l}\text { P. expansum inoculation, then hot } \\
\text { water dipping ( } 2 \% \text { acetic acid, } \\
\left.50{ }^{\circ} \mathrm{C}, 3 \mathrm{~min}\right)\end{array}$ & $\begin{array}{c}\text { Red } \\
\text { Delicious apple }\end{array}$ & $1 \times 10^{5}$ & $73.8 \%$ & $2.2 \%$ & ND & ND & [129] \\
\hline & \multirow{7}{*}{$\begin{array}{l}\text { Biocontrol } \\
\text { agents }\end{array}$} & $\begin{array}{l}\text { Metschnikowia pulcherrima } \\
\text { BIO126 }\left(10^{8} \text { cell } / \mathrm{mL}\right)\end{array}$ & \multirow{3}{*}{$\begin{array}{c}\text { Golden } \\
\text { Delicious apple }\end{array}$} & \multirow{3}{*}{$1 \times 10^{5}$} & $100 \%$ & $56.6 \%$ & ND & ND & \multirow{3}{*}{ [130] } \\
\hline & & $\begin{array}{l}\text { M. pulcherrima BIO126 } \\
\left(10^{8} \text { cell } / \mathrm{mL}\right) \text { with } 10 \% \text { ethanol }\end{array}$ & & & $100 \%$ & $52.3 \%$ & ND & ND & \\
\hline & & $\begin{array}{l}\text { M. pulcherrima BIO126 } \\
\left(10^{8} \text { cell } / \mathrm{mL}\right) \text { with } 3.0 \% \\
\text { sodium bicarbonate }\end{array}$ & & & $100 \%$ & $56.2 \%$ & ND & ND & \\
\hline & & $\begin{array}{l}\text { Rhodosporidium paludigenum } \\
\left(10^{7} \text { cell } / \mathrm{mL}\right)\end{array}$ & Fuji apple & $1 \times 10^{5}$ & $100 \%$ & $67 \%$ & $0.001 \mathrm{mg} / \mathrm{kg}$ & $0.03 \mathrm{mg} / \mathrm{kg}$ & [131] \\
\hline & & $\begin{array}{l}\text { Pichia caribbica } \\
\left(1 \times 10^{8} \text { cells } / \mathrm{mL}\right)\end{array}$ & Fuji apple & $1 \times 10^{5}$ & ND & ND & $29 \mathrm{mg} / \mathrm{kg}$ & $2 \mathrm{mg} / \mathrm{kg}$ & [132] \\
\hline & & $\begin{array}{l}\text { Cryptococcus laurentii LS28 } \\
\left(1 \times 10^{6} \text { cells } / \mathrm{mL}\right) \text { and Lentinula } \\
\text { edodes LF23 }(2 \% w / v)\end{array}$ & $\begin{array}{c}\text { Golden } \\
\text { delicious apple }\end{array}$ & $1 \times 10^{4}$ & $100 \%$ & 0 & $0.47 \mathrm{mg} / \mathrm{kg}$ & $0.005 \mathrm{mg} / \mathrm{kg}$ & [133] \\
\hline & & $\begin{array}{l}\text { Metschnikowia fructicola AL27 } \\
\left(1 \times 10^{8} \text { cells } / \mathrm{mL}\right)\end{array}$ & $\begin{array}{c}\text { Golden } \\
\text { delicious apple }\end{array}$ & $1 \times 10^{5}$ & ND & ND & $>1 \mathrm{mg} / \mathrm{kg}$ & $0 \mathrm{mg} / \mathrm{kg}$ & [80] \\
\hline & \multirow{2}{*}{$\begin{array}{l}\text { Natural } \\
\text { chemicals }\end{array}$} & $\begin{array}{l}\text { Quercetin or umbelliferone } \\
(100 \mu \mathrm{g})\end{array}$ & $\begin{array}{c}\text { Golden } \\
\text { Delicious apple }\end{array}$ & $5 \times 10^{4}$ & $100 \%$ & $8 \%$ or $14 \%$ & $65 \mathrm{mg} / \mathrm{kg}$ & $\begin{array}{l}42 \mathrm{mg} / \mathrm{kg} \text { or } \\
40 \mathrm{mg} / \mathrm{kg}\end{array}$ & [134] \\
\hline & & $\begin{array}{l}\text { Bamboo leaf flavonoid } \\
(0.01 \% w / v)\end{array}$ & Fuji apple & $1 \times 10^{5}$ & ND & ND & $29 \mathrm{mg} / \mathrm{kg}$ & $2 \mathrm{mg} / \mathrm{kg}$ & [132] \\
\hline
\end{tabular}


Table 3. Cont

\begin{tabular}{|c|c|c|c|c|c|c|c|c|c|}
\hline \multirow{2}{*}{ Category } & \multirow{2}{*}{ Method } & \multirow{2}{*}{ Description } & \multirow{2}{*}{$\begin{array}{c}\text { Type of } \\
\text { Apple Products }\end{array}$} & \multirow{2}{*}{$\begin{array}{c}\text { P. expansum Spore } \\
\text { Suspension (spores } / \mathrm{mL} \text { ) }\end{array}$} & \multicolumn{2}{|c|}{ Blue Mold Decay Incidence } & \multicolumn{2}{|c|}{ Patulin Content } & \multirow[t]{2}{*}{ Reference } \\
\hline & & & & & Control & Treatment & Control & Treatment & \\
\hline \multirow{3}{*}{$\begin{array}{l}\text { Before } \\
\text { P. expansum } \\
\text { inoculation }\end{array}$} & \multirow{3}{*}{ Spray elicitor } & $\beta$-Aminobutyric acid (50 mM) & $\begin{array}{c}\text { Golden } \\
\text { Delicious apple }\end{array}$ & $1 \times 10^{4}$ & $100 \%$ & $36.6 \%$ & ND & ND & [135] \\
\hline & & Ammonium molybdate (5 mM) & $\begin{array}{c}\text { Golden } \\
\text { Delicious apple }\end{array}$ & $1 \times 10^{4}$ & $88 \%$ & $9 \%$ & ND & ND & [127] \\
\hline & & $\begin{array}{l}\text { M. pulcherrima BIO126 } \\
\left(10^{8} \text { cell/mL) and }\right. \\
\text { acibenzolar-S-methyl }(1 \mathrm{mg} / \mathrm{mL})\end{array}$ & $\begin{array}{c}\text { Golden } \\
\text { Delicious apple }\end{array}$ & $1 \times 10^{5}$ & $100 \%$ & $57.4 \%$ & ND & ND & [130] \\
\hline \multirow{13}{*}{$\begin{array}{l}\text { After } \\
\text { P. expansum } \\
\text { inoculation }\end{array}$} & $\begin{array}{c}\text { Heat } \\
\text { treatment }\end{array}$ & $\begin{array}{l}\text { Hot water dipping } \\
\left(45^{\circ} \mathrm{C}, 10 \mathrm{~min}\right)\end{array}$ & Ultima Gala apple & $1 \times 10^{4}$ & $90 \%$ & $60 \%$ & ND & ND & [128] \\
\hline & \multirow{7}{*}{$\begin{array}{l}\text { Non-thermal } \\
\text { processing }\end{array}$} & Pulsed light $\left(35.8 \mathrm{~J} / \mathrm{cm}^{2}, 30 \mathrm{~s}\right)$ & Apple juice & ND & ND & ND & $129 \mathrm{mg} / \mathrm{L}$ & $22.38 \mathrm{mg} / \mathrm{L}$ & [136] \\
\hline & & Pulsed light $\left(11.9 \mathrm{~J} / \mathrm{cm}^{2}, 20 \mathrm{~s}\right)$ & Apple puree & ND & ND & ND & $90 \mathrm{mg} / \mathrm{kg}$ & $<\mathrm{LOD}$ & \\
\hline & & $\begin{array}{l}\text { High hydrostatic pressure } \\
\left(400 \mathrm{MPa}, 30^{\circ} \mathrm{C}, 5 \mathrm{~min}\right)\end{array}$ & Apple juice & ND & ND & ND & $0.05 \mathrm{mg} / \mathrm{L}$ & $0.024 \mathrm{mg} / \mathrm{L}$ & [137] \\
\hline & & $\begin{array}{l}\text { High hydrostatic pressure } \\
\text { (600 MPa, } 5 \mathrm{~min})\end{array}$ & $\begin{array}{l}\text { Apple and } \\
\text { spinach juice }\end{array}$ & ND & ND & ND & $0.2 \mathrm{mg} / \mathrm{L}$ & $0.157 \mathrm{mg} / \mathrm{L}$ & [138] \\
\hline & & & Apple cider & ND & ND & ND & $1 \mathrm{mg} / \mathrm{L}$ & $0.125 \mathrm{mg} / \mathrm{L}$ & \multirow{3}{*}{ [139] } \\
\hline & & $\begin{array}{l}\text { UV }(253.7 \mathrm{~nm}, \\
\left.3.00 \mathrm{~mW} / \mathrm{cm}^{2}, 40 \mathrm{~min}\right)\end{array}$ & $\begin{array}{l}\text { Apple juice } \\
\text { without } \\
\text { ascorbic acid }\end{array}$ & ND & ND & ND & $1 \mathrm{mg} / \mathrm{L}$ & $0.052 \mathrm{mg} / \mathrm{L}$ & \\
\hline & & & $\begin{array}{l}\text { Apple juice with } \\
\text { ascorbic acid }\end{array}$ & ND & ND & ND & $1 \mathrm{mg} / \mathrm{L}$ & $0.014 \mathrm{mg} / \mathrm{L}$ & \\
\hline & \multirow{3}{*}{ Adsorption } & $\begin{array}{l}\text { Cross-linked xanthated chitosan } \\
\text { resin }\left(\mathrm{pH} 4,30^{\circ} \mathrm{C}, 18 \mathrm{~h}, 0.01 \mathrm{~g}\right)\end{array}$ & Apple juice & ND & ND & ND & $300 \mathrm{mg} / \mathrm{L}$ & $170 \mathrm{mg} / \mathrm{L}$ & [140] \\
\hline & & $\begin{array}{l}\text { Calcium carbonate immobilized } \\
\text { porcine pancreatic lipase } \\
\left(40^{\circ} \mathrm{C}, 18 \mathrm{~h}, 0.03^{\prime} \mathrm{g} / \mathrm{mL}\right)\end{array}$ & Apple juice & ND & ND & ND & $1 \mathrm{mg} / \mathrm{L}$ & $<0.3 \mathrm{mg} / \mathrm{L}$ & [141] \\
\hline & & $\begin{array}{l}\text { Caustic treated waste cider } \\
\text { yeast biomass }\end{array}$ & Apple juice & ND & ND & ND & $0.1 \mathrm{mg} / \mathrm{L}$ & $0.04 \mathrm{mg} / \mathrm{L}$ & [142] \\
\hline & \multirow{2}{*}{$\begin{array}{l}\text { Natural } \\
\text { chemicals }\end{array}$} & Propolis (2 mg/mL) & $\begin{array}{l}\text { Fresh pressed } \\
\text { apple juice }\end{array}$ & $0.4 \times 10^{4} \sim 5 \times 10^{4}$ & ND & ND & $0.056 \mathrm{mg} / \mathrm{L}$ & $0.028 \mathrm{mg} / \mathrm{L}$ & [143] \\
\hline & & $\begin{array}{l}\text { Gaseous ozone } \\
(12 \mathrm{mg} / \mathrm{L}, 10 \mathrm{~min})\end{array}$ & Apple juice & ND & ND & ND & $0.247 \mathrm{mg} / \mathrm{L}$ & $0.018 \mathrm{mg} / \mathrm{L}$ & [144] \\
\hline
\end{tabular}




\subsubsection{Selection of Blue Mold Resistant Apple Cultivars}

During recent years, a growing number of studies have sought apple cultivars with superior resistance to P. expansum. This strategy aims to reduce the decay and accumulation of patulin in apples, even the damaged ones selected from blue mold-resistant apple cultivars. Wild apples with a naturally strong resistance to disease have been considered as promising and sustainable sources in resistant apple breeding, of which $M$. sieversii is the most prominent. With the identification of the qM-Pe3.1 QTL among resistant $M$. sieversii, we hope to use these disease resistance alleles in introgression breeding or to act as the molecular markers that help with accelerating the screening of a resistant apple progeny [60]. The value of resistant apple cultivars has also been realized by scientists from Sweden and Norway, who selected 12 apple cultivars with a high resistance to P. expansum and an adaptability to cold weather [124]. Further investigations will be needed to breed new apple cultivars by exploring new fungal virulence genes and pathways, which regulate $P$. expansum virulence and patulin production. To meet consumers' needs, the organoleptic qualities of new apple cultivars should also be taken into consideration, because domesticated apple varieties are significantly bigger, firmer, and sweeter than M. sieversii from Kazakhstan [145].

\subsubsection{Good Management Practices in Apple Orchards}

Good agricultural practices and orchard-management are important in enhancing the storage quality of apples from planting to harvesting, and contribute further to lowering the levels of rotten apples and patulin contaminations.

In orchards, dispersed spores may randomly land on a fruit's surface by wind or agricultural activities like mowing. Meanwhile, practices such as pruning, mulching, thinning, and fertilizing have varying effects on the prevalence of Penicillium rot in apples [146]. Evidence shows that summer pruning (in July and August), bark mulching, and hand thinning positively improved the productivity and/or storability of early season "Katja" and several other organically grown apple cultivars (e.g., "Dayton", "Delorina", "Santana", "Sultanat", and "Zarya Alatau" in Sweden) [124,147]. Mulching practices, especially cornstalk treatment, also significantly improved the firmness of apples from Loess Plateau (China), which may be beneficial in reducing disease incidence and patulin contaminations [148].

During apple harvesting and handling, precautions should be taken to minimize apple bruising and wounding [123]. The selection of an optimal harvest date is also important, as the occurrence of severe rot is more likely to happen in late-harvested apples than in earlier ones [149]. To predict an optimal picking date for various cultivars, the Streif index is widely used as an indicator that relies on firmness, soluble solids content, and starch value [65]. In terms of recommended values, this index is lower in unripe fruit and higher in over-ripe fruit. The "Aroma" apple, which, when picked two weeks after normal harvest time, showed higher incidents of blue mold [149]. Another feasible way to determine the optimal harvest dates is by calculating the days after full bloom (DAFB). However, a lower decay index was observed in both early- or late-ripening apple cultivars, which were harvested at higher DAFB [124]. Therefore, the combination of the Streif index and DAFB in harvest dates determination could extend the shelf-life of apples and, more importantly, result in less decay and patulin accumulation.

After harvest, fresh apples are usually sent to the warehouse for long-term storage. A hot water washing step before the subsequent storage seems very promising in reducing mold infection and patulin concentrations [130]. Heat shock proteins induced by such a heat treatment could further prepare apples for pathogen attack [128]. Therefore, implementing proper management in orchards and procedures after harvest will contribute to a better control of the P. expansum spread, lowering the level of patulin contaminations within the final products. 


\subsubsection{Preharvest Application of Plant Elicitors}

Plant elicitors, if within the right dosage, can elevate the expression of defense-related genes and increase activities of resistance-associated enzymes in fruits [150]. In that case, preharvest treatment with a small number of elicitors could effectively trigger apple resistance to $P$. expansum, and thus, reduce patulin production in apples. In a recent study, the spraying of a $20 \mathrm{mg} / \mathrm{L}$ harpin solution on trees 4-8 days prior to the harvest helped in reducing the P. expansum infection from $32 \%$ to $5-10 \%$ and from 30\% to 4\% in "Empire" and "Red Delicious" apples, respectively [126]. Blue mold decay on "Golden Delicious" apples was significantly reduced after applying $1 \mathrm{mM}$ of ammonium molybdate in some orchards [127]. The effectiveness of these elicitors on inducing apples' resistance is largely dependent on the type, dosage, P. expansum population, and the timing of treatment (before or after harvest) $[130,135,151]$. Taking harpin as an example, $40 \mathrm{mg} / \mathrm{L}$ harpin was required after harvest to achieve equivalent effects of $20 \mathrm{mg} / \mathrm{L}$ applied before harvest [126]. Before the large-scale usage of these elicitors, more investigation on the dosage, application time(s), and safety evaluations are needed.

\subsection{Postharvest Control of Patulin Contamination in Apples and Apple-Products}

Once decayed apples enter juice-manufacturing process, it is hard to remove the patulin from the final products. Green and effective methods are needed to meet consumers' demand for safe and additive-free food preparations. From apple storage to processing, a series of non-thermal and natural detoxification or degradation strategies have been developed to efficiently reduce or remove patulin from apples or apple-products (Table 3).

\subsubsection{Control of Patulin Production during Apple Storage}

Given the fact that contaminations with P. expansum are unavoidable, and that they are responsible for blue mold decay in apples, it is of great importance to prevent mold growth and mycotoxin production during storage. To lower the incidence of apple blue mold, the hygiene of warehouses is of utmost importance. The chances of infection and/or the colonization of P. expansum in injured apples are greatly reduced in storage rooms with good sanitary conditions [32]. Moreover, temperature, atmospheric composition, and moisture levels are also considered as critical components to the proper storage of apples. Low temperatures have been widely used in commercial apple storage, for their suppression of P. expansum growth [152]. Recently, controlled atmospheres $\left(1.00-3.00 \% \mathrm{O}_{2}\right.$ and $0.03-5.00 \% \mathrm{CO}_{2}$ ) and/or ethylene content adjustments through the spraying of 1-methylcyclopropene have been coupled with cold storage practices to better extend the shelf-lives of apples and to inhibit P. expansum spreading $[46,153,154]$. Although patulin is commonly found during a later storage phase, a high density of P. expansum spores could result in a large amount of patulin accumulating in apples, even at an earlier onset of cold storage $[44,155]$. Therefore, a new trend of applying biocontrol agents (i.e., antagonistic yeast cultures) in cold and hypoxic warehouses has been tested, showing their ability to synergistically inhibit $P$. expansum growth and patulin accumulation [156,157]. As a critical control point in the commercial production of apples, the improvement of storage conditions will bring a multiplier effect in controlling apple blue mold decay and patulin accumulation within processed apple products.

\subsubsection{Mitigation of Patulin Contamination during Apple Processing}

After a certain period of storage, apples are supplied to grocery stores or are processed into apple products. Treatments like the culling or sorting damaged fruits and the hot water washing/dipping apple fruits ahead of further pressing are proven to be useful and feasible in reducing patulin contamination. The patulin content in unfermented apple cider made from unculled apples could reach $59.9 \mu \mathrm{g} / \mathrm{L}-120.5 \mu \mathrm{g} / \mathrm{L}$, but only reach $0-15.1 \mu \mathrm{g} / \mathrm{L}$ in the cider from culled ones [158]. In a recent study and after an ambient storage for 21-93 days, the level of patulin in "McIntosh", "Gala", "Fuji", and "Golden Supreme" varied from $5920 \mu \mathrm{g} / \mathrm{kg}$ to $54,221 \mu \mathrm{g} / \mathrm{kg}$ [79], which could benefit from 
a carefully established culling and prevent patulin levels from exceeding the regulatory upper limits within the final products. By sorting out apples with moldy spots over $10 \mathrm{~cm}^{2}$, another study showed that the contents of patulin was reduced from $15.8 \mu \mathrm{g} / \mathrm{kg}$ to $1.1 \mu \mathrm{g} / \mathrm{kg}$ and from $8.3 \mu \mathrm{g} / \mathrm{kg}$ to $0.6 \mu \mathrm{g} / \mathrm{kg}$ in cloudy and clear apple juice, respectively [155]. Water treatment on apples also showed a reduction of patulin in the final products. During the processing of apple juice concentrate, the washing stage contributed to a $33.6 \%$ reduction of patulin and, thus, is considered as the most effective procedure when compared to an enzymatic treatment (9.9\% reduction) or micro-filtration (3.7\% reduction) [12]. In apple puree production, a pulping step (i.e., A step to remove peel and cores from apple mash by a pulper with $4 \mathrm{~mm}$ and $1.25 \mathrm{~mm}$ sieves) before pasteurization also led to an $80 \%$ degradation of patulin [84]. The disappearance of patulin has been observed after the alcoholic fermentation of apple juice [159]. The abovementioned procedures in apple processing, except alcoholic fermentation, are practical and economic ways that are expected to reduce patulin contamination in processed apple products intended for adult or child consumption alike.

\subsubsection{Reduction of Patulin Contamination from Apple Products}

Ideally, detoxification procedures should not only reduce the content of toxins to safe levels, but also prevent any reduction of the nutritional and palatable values of the treated commodity. In the past, strategies that were applied to reduce patulin contamination in apple products were either physical or chemical. The trend in patulin detoxification has evolved from traditional methods to environmental friendly non-thermal treatments, natural extracts, and biological control agents and their combinations, in order to exert additive even synergistic effects.

Novel physical technologies have gained attention in the mitigation of patulin from processed apple products, including the application of irradiation, high hydrostatic pressure, and adsorbents [160]. Approximately $90 \%$ of $1000 \mu \mathrm{g} / \mathrm{L}$ patulin was removed from extreme UVC (ultraviolet light with wavelength at $222 \mathrm{~nm}$ ) treated apple juice and cider [139]. Unfortunately, a supplementation is required to remedy the loss of ascorbic acid and other photosensitive substances after the UV treatment. To keep most of the color and natural flavor of liquid apple products, high hydrostatic pressure and ozone detoxification techniques are also applied in patulin detoxification. In mixed apple juice, $30 \%$ of the patulin was eliminated in a high pressure treatment at $600 \mathrm{MPa}$ for $300 \mathrm{~s}$ [138]. However, the effect of high hydrostatic pressure on patulin degradation highly relies on thiol concentration of juices [40]. More than $90 \%$ patulin was removed from the juice through the physical adsorption with chitosan-coated $\mathrm{Fe}_{3} \mathrm{O}_{4}$ particles or water-insoluble corn flour [161,162]. Moreover, the patulin was reduced from $198.36 \mu \mathrm{g} / \mathrm{L}$ to $48.92 \mu \mathrm{g} / \mathrm{L}$ in concentrated apple juice when a self-developed gaseous ozone equipment was set at $12 \mathrm{mg} / \mathrm{L}$ ozone purging for $15 \mathrm{~min}$ ozonation [144]. The above data collectively shows that non-thermal treatments are indeed promising approaches for controlling patulin contamination if the diminishment of nutritional compounds and the possibility of patulin desorption could be addressed in the near future.

During the development of alternatives to fungicides, green and natural compounds have grabbed researchers' attention. Among them, natural antioxidants, plant extracts, and essential oils, showed the ability to suppress the growth of $P$. expansum or the synthesis of patulin. In apple juice that was inoculated with $P$. expansum, the addition of $2 \mathrm{mg} / \mathrm{L}$ of Turkish propolis (a natural honeybee hive product) inhibited patulin synthesis from $30.47 \mu \mathrm{g} / \mathrm{L}$ in the first day of storage to $27.63 \mu \mathrm{g} / \mathrm{L}$ after $48 \mathrm{~h}$ $(p<0.001)$; while the patulin content in the control was $26.06 \mu \mathrm{g} / \mathrm{L}$ and $56.40 \mu \mathrm{g} / \mathrm{L}$, respectively [143]. Similarly, the application of a $0.01 \%(w / v)$ bamboo leaf flavonoid inhibited blue mold decay and patulin accumulation, with $0.029 \mu \mathrm{g} / \mathrm{kg}$ in untreated apples and $0.002 \mu \mathrm{g} / \mathrm{kg}$ in treated apples after 20 days of storage at $20{ }^{\circ} \mathrm{C}$ [132]. In the presence of $10 \%$ of the supernatant of Kombucha (a fermented drink made from black tea, sucrose, acetic acid bacteria, and yeast), a $49.8 \%$ inhibition of patulin production has been observed in P. expansum inoculated apples [163]. A micro-emulsified essential oil prepared from the leaves of betel vine $(\geq 0.5 \mu \mathrm{L} / \mathrm{mL})$ also showed promising antifungal effects, especially for the inhibition of mycelial growth of P. expansum in apple juice [164]. Antioxidants like 
ascorbic acid could accelerate the degradation of patulin in apple juice as well [165]. As these bioactive compounds have long been used as food additives or food preservatives, it is hopeful to exploit their abilities against blue mold decay and patulin accumulation within the food industries.

Microorganisms have been always considered as promising candidates in reducing the exposure to mycotoxins from infected food crops and fruits. Some biocontrol agents are able to adsorb mycotoxins from an aqueous solution, and others can even transform te mycotoxin into less toxic or non-toxic products [166]. Antagonistic yeasts are the most popular biological tools against the blue mold decay of apples in cold or deck storage (Table 4). Known as brewer's yeast, Saccharomyces cerevisiae commonly biodegrades patulin to $E$-ascladiol via the alcoholic fermentation of apple juice to hard cider [159]. Furthermore, a spray developed from a culture filtrate of $S$. cerevisiae contributed to a $48 \%$ reduction of blue mold decay and a $42.6 \%$ reduction of patulin accumulation in "Golden Delicious" apples [167]. Similarly, the decay incidence was dropped from $65.6 \%$ to $35.6 \%$ when stored apples were treated with Pichia caribbica [168]. As effective as fungicides (imazalil and pyrimethanil), Metschnikowia fructicola inhibited P. expansum when apples were stored at $1{ }^{\circ} \mathrm{C}$ for 56 days [80]. Apples that were treated with Rhodosporidium paludigenum also showed a $67 \%$ and $100 \%$ reduction in the decay incidence and patulin concentration, respectively [131]. Moreover, viable bacteria could biodegrade the patulin effectively. Up to $96 \%$ of the patulin was degraded by Gluconobacter oxydans in apple juices [169]. Pseudomonas fluorescens strain 2-28 was able to reduce the blue mold incidence by $88 \%$ in "Spartan" apples, which was comparable to fungicide Scholar ${ }^{\circledR}$ or the registered decay biocontrol agent, Bio-Save ${ }^{\circledR}[170]$. The adsorption of patulin from an aqueous solution has been found in the existence of inactivated Saccharomyces or lactic acid bacterial cells [115,171]. The biocontrol effect of an atoxigenic fungus against patulin-producing fungus has also been investigated most recently. Living cells of atoxigenic Aspergillus flavus HF-B1 were capable of reducing $89.5 \%$ or $62 \%$ of the patulin produced by the toxigenic Aspergillus terreus HPA1 in PDA media or in Egyptian apples, respectively [172]. Enzymes are also recognized as promising biocontrol agents in patulin detoxification. More than $70 \%$ of the patulin was removed when the apple juice was treated with $0.03 \mathrm{~g} / \mathrm{mL}$ calcium carbonated immobilized porcine pancreatic lipase at $40^{\circ} \mathrm{C}$ for $72 \mathrm{~h}$ [141]. 
Table 4. Effect of biocontrol agents on patulin degradation.

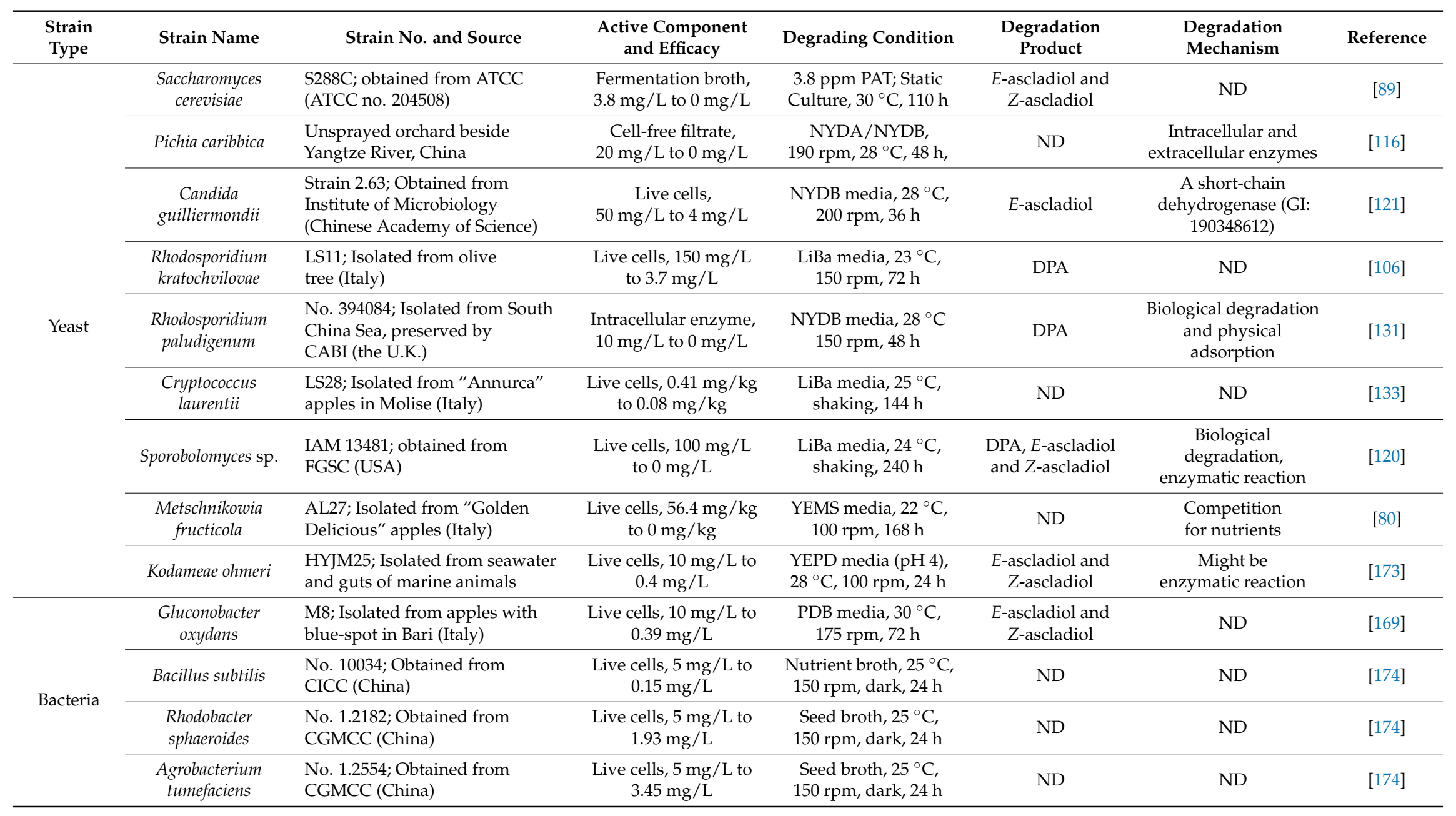


Table 4. Cont.

\begin{tabular}{|c|c|c|c|c|c|c|c|}
\hline \multirow{3}{*}{ Probiotics } & $\begin{array}{l}\text { Lactobacillus } \\
\text { plantarum }\end{array}$ & $\begin{array}{l}\text { S1; isolated from fermented } \\
\text { animal feeds }\end{array}$ & $\begin{array}{l}\text { Cell free supernatant, } \\
100 \mathrm{mg} / \mathrm{L} \text { to } 0 \mathrm{mg} / \mathrm{L}\end{array}$ & MRS broth, $37^{\circ} \mathrm{C}, 4 \mathrm{~h}$ & $\begin{array}{c}\text { E-ascladiol, } \\
\text { Z-ascladiol, and } \\
\text { hydroascladiol }\end{array}$ & ND & [108] \\
\hline & Lactobacillus brevis & $\begin{array}{l}\text { LB-20023; Obtained from } \\
\text { CICC (China) }\end{array}$ & $\begin{array}{l}\text { Heat-inactivated cells, } \\
4 \mathrm{mg} / \mathrm{L} \text { to } 1.4 \mathrm{mg} / \mathrm{L}\end{array}$ & $\begin{array}{l}\text { MRS media, } 37^{\circ} \mathrm{C}, \\
150 \mathrm{rpm}, 48 \mathrm{~h}\end{array}$ & ND & $\begin{array}{c}\text { Binding by } \\
\text { polysaccharides and } \\
\text { proteins from cell wall }\end{array}$ & [171] \\
\hline & $\begin{array}{l}\text { Enterococcus } \\
\quad \text { faecium }\end{array}$ & $\begin{array}{l}\text { EF031; Obtained from } \\
\text { Aroma-Prox (Cedex, France) }\end{array}$ & $\begin{array}{l}\text { Live cells, } 1 \mathrm{mg} / \mathrm{L} \text { to } \\
0.547 \mathrm{mg} / \mathrm{L}\end{array}$ & $\begin{array}{l}\text { BHI broth }(\mathrm{pH} 4), \\
37^{\circ} \mathrm{C} \text {, soft agitation, } \\
48 \mathrm{~h}\end{array}$ & ND & Binding & [175] \\
\hline Fungus & Aspergillus flavus & $\begin{array}{l}\text { HF-B1; Isolated from fruits } \\
\text { in Egypt }\end{array}$ & $\begin{array}{l}\text { Live cells, } 324 \mathrm{mg} / \mathrm{L} \\
\quad \text { to } 34 \mathrm{mg} / \mathrm{L}\end{array}$ & $\begin{array}{l}\text { PDB medium, } 30^{\circ} \mathrm{C}, \\
240 \mathrm{~h}\end{array}$ & ND & ND & [172] \\
\hline
\end{tabular}

ND, not disclosed; DPA, desoxypatulinic acid; CABI, Centre for Agricultural Bioscience International (the United Kingdom); FGSC, Fungal Genetics Stock Centre, University of Missouri (USA); CICC: China Center of Industrial Culture Collection; CGMCC, China General Microbiological Culture Collection Center. 
In order to explore safe and cost-effective substitutes for fungicides, physical practices or chemical treatments have been integrated with biological control agents to exert an additive effect against postharvest diseases in fruits and their products. A recent review by Zhang et al. has summarized the combined application of some of the physical practices and microbial antagonists against patulin [160], among which there is a strong synergistic effect of Cryptococcus laurentii $\left(1 \times 10^{8}\right.$ cells $\left./ \mathrm{mL}\right)$ and chitosan $(0.1 \%$, viscosity $12 \mathrm{cP})$, leading to an $86 \%$ reduction in blue mold decay within wounded apples [176]. Similarly, the culture filtrate of the edible mushroom Lentinula edodes greatly improved the biocontrol activity of $C$. laurentii against $P$. expansum (a reported enhancement from $85 \%$ to $100 \%$ ), coupled with an increased patulin reduction capacity (from 77\% to 99\%), respectively [133]. Moreover, Rhodotorula mucilaginosa at $1 \times 10^{8}$ cells $/ \mathrm{mL}$ combined with phytic acid at $4 \mu \mathrm{mol} / \mathrm{mL}$ created an additive effect on the reduction of the patulin content in apples [177]. In a similar fashion, Pichia caribbica $\left(1 \times 10^{8}\right.$ cells $\left./ \mathrm{mL}\right)$ and bamboo leaf flavonoids $(0.01 \% \mathrm{w} / v)$ together significantly inhibited the P. expansum growth and reduced the patulin accumulation [132]. In essence, the exploration of integrated strategies could be a promising method against postharvest blue mold rot and patulin accumulation in apples.

\section{Conclusions and Future Prospect}

Apple fruits and apple products, particularly apple juice, play a major role in human exposure to patulin. The in-depth investigations of the factors and challenges associated with blue mold decay in apples and patulin accumulation in apple-products are essential in order to develop methods that can effectively reduce or remove patulin from the human dietary route. Modulated by environment conditions, interactions between pathogenicity of Penicillium species and susceptibility of apple cultivars lead to differences in the severity of blue mold decay and levels of patulin accumulation in apples. The high density of a toxigenic pathogen like P. expansum in storage rooms is an indispensable element for patulin production in apples. Moreover, the existence of atoxigenic pathogens could also accelerate the development of blue mold decay. Although injured or bruised apples can hardly avoid pathogen attack, apples with one or more characters like fast wound healing or defense mechanisms, such as relatively firm fruits, lower ethylene production levels, and abundant polyphenols, are less likely to accumulate patulin. The physiochemical characteristics of patulin make it easy for this toxin to survive cold, hypoxic, acidic, or high-temperature conditions. In addition, these properties coupled with the complexity food matrixes, interfere the accurate detection of patulin residues in apple products. To mitigate the patulin content in apple-products, newly developed strategies that are safer and more effective compared with the use of synthetic fungicides are needed. Generally, strategies intended to mitigate patulin contamination from preharvest to postharvest mainly focus on improving the disease resistance of apples, or reducing the patulin content indirectly by controlling apple blue mold, or directly by degrading the accumulated toxin. However, it takes years or up to decades to breed new apple cultivars, which have combined resistant abilities to blue mold, as well as the superior quality traits (e.g., bigger size and/or sweet flavor). The resistance of apples can also be improved by the application of biological elicitors with properly calculated/adjusted dosages. Good agricultural practices and orchard-management could also help maintain the storage quality of apples, so that they have a limited effect on disease development. Except for the basic setup of low temperature and controlled atmospheres, the application of ethylene inhibitors or biocontrol agents on apples during storage could additively control patulin accumulation by suppressing P. expansum growth. Practices like culling rotten apples and/or washing with hot water prior to juice pressing are simple yet effective means that are highly recommended. UV and high hydrostatic pressure processing are non-thermal treatments for patulin reduction and have showed limited yet promising successes, at least within the laboratory settings. However, the loss of nutrients and the high cost of the needed instruments could jeopardize their large-scale industrial applications. The addition of green antifungal reagents, such as plant extracts or essential oils, could help reduce the patulin content in apple juice. The commercial application of these natural chemicals in juice production pipelines is obstructed by the economic costs 
of extraction and concentration steps. By far, the most promising method in patulin reduction is the use of biological control agents that consist of antagonistic yeasts, bacteria, and atoxigenic fungi. Some of these agents can completely and efficiently degrade patulin in vivo or in vitro. However, the toxicity of patulin-degradation by-products and the mechanism(s) behind cellular patulin detoxifications are still not clear and should be intensively investigated. Given the substrate speciality of detoxifying enzymes, patulin-degrading enzyme(s) from antagonistic strains may have great potential for patulin removal from apple products. Collectively, efforts are still needed to make children and adults feel safe while enjoying the health benefits of their desirable processed apple-based products, without concerns with regard to patulin contamination.

Author Contributions: L.Z. wrote the manuscript. J.C., Z.L., T.Z., and F.L. edited and reviewed the manuscript.

Funding: This research was funded by Agriculture and Agri-Food Canada.

Acknowledgments: L.Z. is supported by a joint Ph.D. program from the China Scholarship Council (CSC). The authors thank Yousef I. Hassan, Yan Zhu, Suqin Shao, and Xiu-Zhen Li for the valuable discussions.

Conflicts of Interest: The authors declare no conflicts of interest.

\section{References}

1. Le Gall, S.; Even, S.; Lahaye, M. Fast estimation of dietary fiber content in apple. J. Agric. Food Chem. 2016, 64, 1401-1405. [CrossRef] [PubMed]

2. Kalinowska, M.; Bielawska, A.; Lewandowska-Siwkiewicz, H.; Priebe, W.; Lewandowski, W. Apples: Content of phenolic compounds vs. variety, part of apple and cultivation model, extraction of phenolic compounds, biological properties. Plant Physiol. Biochem. 2014, 84, 169-188. [CrossRef] [PubMed]

3. FAOSTAT. FAO Statistical Database; FAO: Rome, Italy, 2012.

4. Nunes, C.A. Biological control of postharvest diseases of fruit. Eur. J. Plant Pathol. 2012, 133, $181-196$. [CrossRef]

5. Moake, M.M.; Padilla Zakour, O.I.; Worobo, R.W. Comprehensive review of patulin control methods in foods. Compr. Rev. Food Sci. Food Saf. 2005, 4, 8-21. [CrossRef]

6. JECFA. 44th Report of the Joint FAO/WHO Expert Committee on Food Additives; FAO: Rome, Italy, 1995.

7. EC. Commission Regulation (EC) No. 1881/2006 of 19 December 2006 Setting Maximum Levels for Certain Contaminants in Foodstuffs; Official Journal of the European Communities: Brussels, Belgium, 2006; Volume L364, pp. 5-24.

8. US-FDA. CPG Sec. 510.150 Apple Juice, Apple Juice Concentrates, and Apple Juice Products-Adulteration with Patulin; Food and Drug Administration: Silver Spring, MD, USA, 2005.

9. Ministry of Health of the People's Republic of China. GB 2761-2011 of 20 April 2011 China National Food Safety Standard: Maximum Limit of Mycotoxins in Food; Ministry of Health of the People's Republic of China: Beijing, China, 2014.

10. Health Canada. Summary of Comments from Health Canada's Consultation on Its Proposal to Introduce a Maximum Level for the Presence of Patulin in Apple Juice and Unfermented Apple Cider Sold in Canada; Health Canada: Ottawa, ON, USA, 2012.

11. USDA. Fresh Apples, Graps, and Pears: World Markets and Trade; United States Department of Agriculture: Washington, DC, USA, 2018.

12. Yuan, Y.; Zhuang, H.; Zhang, T.; Liu, J. Patulin content in apple products marketed in Northeast China. Food Control 2010, 21, 1488-1491. [CrossRef]

13. Guo, Y.; Zhou, Z.; Yuan, Y.; Yue, T. Survey of patulin in apple juice concentrates in Shaanxi (China) and its dietary intake. Food Control 2013, 34, 570-573. [CrossRef]

14. Szymczyk, K.; Szteke, B.; Goszcz, H. Patulin content in Polish apple juices. Rocz. Panstw. Zakl. Hig. 2004, 55, 255-260. [PubMed]

15. Spadaro, D.; Ciavorella, A.; Frati, S.; Garibaldi, A.; Gullino, M. Incidence and level of patulin contamination in pure and mixed apple juices marketed in Italy. Food Control 2007, 18, 1098-1102. [CrossRef]

16. Harris, K.L.; Bobe, G.; Bourquin, L.D. Patulin surveillance in apple cider and juice marketed in Michigan. J. Food Prot. 2009, 72, 1255-1261. [CrossRef] [PubMed] 
17. Iqbal, S.Z.; Malik, S.; Asi, M.R.; Selamat, J.; Malik, N. Natural occurrence of patulin in different fruits, juices and smoothies and evaluation of dietary intake in Punjab, Pakistan. Food Control 2018, 84, 370-374. [CrossRef]

18. Ji, X.; Li, R.; Yang, H.; Qi, P.; Xiao, Y.; Qian, M. Occurrence of patulin in various fruit products and dietary exposure assessment for consumers in China. Food Control 2017, 78, 100-107. [CrossRef]

19. Barreira, M.J.; Alvito, P.C.; Almeida, C.M. Occurrence of patulin in apple-based-foods in Portugal. Food Chem. 2010, 121, 653-658. [CrossRef]

20. Murillo-Arbizu, M.; Amézqueta, S.; González-Peñas, E.; de Cerain, A.L. Occurrence of patulin and its dietary intake through apple juice consumption by the Spanish population. Food Chem. 2009, 113, 420-423. [CrossRef]

21. Piqué, E.; Vargas-Murga, L.; Gómez-Catalán, J.; de Lapuente, J.; Llobet, J.M. Occurrence of patulin in organic and conventional apple-based food marketed in Catalonia and exposure assessment. Food Chem. Toxicol. 2013, 60, 199-204. [CrossRef] [PubMed]

22. Torović, L.; Dimitrov, N.; Lopes, A.; Martins, C.; Alvito, P.; Assunção, R. Patulin in fruit juices: Occurrence, bioaccessibility, and risk assessment for Serbian population. Food Addit. Contam. Part A 2018, 1-11. [CrossRef] [PubMed]

23. Oteiza, J.M.; Khaneghah, A.M.; Campagnollo, F.B.; Granato, D.; Mahmoudi, M.R.; Sant'Ana, A.S.; Gianuzzi, L. Influence of production on the presence of patulin and ochratoxin A in fruit juices and wines of Argentina. LWT-Food Sci. Technol. 2017, 80, 200-207. [CrossRef]

24. Zaied, C.; Abid, S.; Hlel, W.; Bacha, H. Occurrence of patulin in apple-based-foods largely consumed in Tunisia. Food Control 2013, 31, 263-267. [CrossRef]

25. Lee, T.P.; Sakai, R.; Manaf, N.A.; Rodhi, A.M.; Saad, B. High performance liquid chromatography method for the determination of patulin and 5-hydroxymethylfurfural in fruit juices marketed in Malaysia. Food Control 2014, 38, 142-149. [CrossRef]

26. Funes, G.; Resnik, S. Determination of patulin in solid and semisolid apple and pear products marketed in Argentina. Food Control 2009, 20, 277-280. [CrossRef]

27. Bonerba, E.; Conte, R.; Ceci, E.; Tantillo, G. Assessment of dietary intake of patulin from baby foods. J. Food Sci. 2010, 75, T123-T125. [CrossRef] [PubMed]

28. Juan, C.; Raiola, A.; Mañes, J.; Ritieni, A. Presence of mycotoxin in commercial infant formulas and baby foods from Italian market. Food Control 2014, 39, 227-236. [CrossRef]

29. Marín, S.; Mateo, E.M.; Sanchis, V.; Valle-Algarra, F.M.; Ramos, A.J.; Jiménez, M. Patulin contamination in fruit derivatives, including baby food, from the Spanish market. Food Chem. 2011, 124, 563-568. [CrossRef]

30. Sanzani, S.; Reverberi, M.; Punelli, M.; Ippolito, A.; Fanelli, C. Study on the role of patulin on pathogenicity and virulence of Penicillium expansum. Int. J. Food Microbiol. 2012, 153, 323-331. [CrossRef] [PubMed]

31. Amiri, A.; Bompeix, G. Diversity and population dynamics of Penicillium spp. on apples in pre-and postharvest environments: Consequences for decay development. Plant Pathol. 2005, 54, 74-81. [CrossRef]

32. Morales, H.; Marín, S.; Ramos, A.J.; Sanchis, V. Influence of post-harvest technologies applied during cold storage of apples in Penicillium expansum growth and patulin accumulation: A review. Food Control 2010, 21, 953-962. [CrossRef]

33. FAO. Code of Practice for the Prevention and Reduction of Patulin Contamination in Apple Juice and Apple Juice Ingredients in Other Beverages; In CAC/RPC; FAO: Rome, Italy, 2003; Volume 50, pp. 1-6.

34. Soliman, S.; Li, X.-Z.; Shao, S.; Behar, M.; Svircev, A.; Tsao, R.; Zhou, T. Potential mycotoxin contamination risks of apple products associated with fungal flora of apple core. Food Control 2015, 47, 585-591. [CrossRef]

35. Sant'Ana, A.S.; Simas, R.C.; Almeida, C.A.; Cabral, E.C.; Rauber, R.H.; Mallmann, C.A.; Eberlin, M.N.; Rosenthal, A.; Massaguer, P.R. Influence of package, type of apple juice and temperature on the production of patulin by Byssochlamys nivea and Byssochlamys fulva. Int. J. Food Microbiol. 2010, 142, 156-163. [CrossRef] [PubMed]

36. Tannous, J.; Keller, N.P.; Atoui, A.; El Khoury, A.; Lteif, R.; Oswald, I.P.; Puel, O. Secondary metabolism in Penicillium expansum: Emphasis on recent advances in patulin research. Crit. Rev. Food Sci. Nutr. 2017, 58, 2082-2098. [CrossRef] [PubMed]

37. Frisvad, J. A critical review of producers of small lactone mycotoxins: Patulin, penicillic acid and moniliformin. World Mycotoxin J. 2018, 11, 73-100. [CrossRef] 
38. Barad, S.; Sionov, E.; Prusky, D. Role of patulin in post-harvest diseases. Fungal Biol. Rev. 2016, 30, $24-32$. [CrossRef]

39. De Souza Sant'Ana, A.; Rosenthal, A.; de Massaguer, P.R. The fate of patulin in apple juice processing: A review. Food Res. Int. 2008, 41, 441-453. [CrossRef]

40. Ioi, J.D.; Zhou, T.; Tsao, R.; Marcone, M.F. Mitigation of patulin in fresh and processed foods and beverages. Toxins 2017, 9, 157. [CrossRef] [PubMed]

41. Barad, S.; Espeso, E.A.; Sherman, A.; Prusky, D. Ammonia activates pacC and patulin accumulation in an acidic environment during apple colonization by Penicillium expansum. Mol. Plant Pathol. 2016, 17, 727-740. [CrossRef] [PubMed]

42. Eastburn, D.; McElrone, A.; Bilgin, D. Influence of atmospheric and climatic change on plant-pathogen interactions. Plant Pathol. 2011, 60, 54-69. [CrossRef]

43. Morales, H.; Sanchis, V.; Rovira, A.; Ramos, A.J.; Marín, S. Patulin accumulation in apples during postharvest: Effect of controlled atmosphere storage and fungicide treatments. Food Control 2007, 18, 1443-1448. [CrossRef]

44. De Clercq, N.; Vlaemynck, G.; Van Pamel, E.; Colman, D.; Heyndrickx, M.; Van Hove, F.; De Meulenaer, B.; Devlieghere, F.; Van Coillie, E. Patulin production by Penicillium expansum isolates from apples during different steps of long-term storage. World Mycotoxin J. 2016, 9, 379-388. [CrossRef]

45. Sholberg, P.L.; Bedford, K.; Stokes, S. Sensitivity of Penicillium spp. and Botrytis cinerea to pyrimethanil and its control of blue and gray mold of stored apples. Crop Prot. 2005, 24, 127-134. [CrossRef]

46. Dos Santos, I.D.; Pizzutti, I.R.; Dias, J.V.; Fontana, M.E.; Brackmann, A.; Anese, R.O.; Thewes, F.R.; Marques, L.N.; Cardoso, C.D. Patulin accumulation in apples under dynamic controlled atmosphere storage. Food Chem. 2018. [CrossRef] [PubMed]

47. Van Zeebroeck, M.; Ramon, H.; De Baerdemaeker, J.; Nicolaï, B.; Tijskens, E. Impact damage of apples during transport and handling. Postharvest Biol. Technol. 2007, 45, 157-167. [CrossRef]

48. Beretta, B.; Gaiaschi, A.; Galli, C.L.; Restani, P. Patulin in apple-based foods: Occurrence and safety evaluation. Food Addit. Contam. 2000, 17, 399-406. [CrossRef] [PubMed]

49. Ballester, A.-R.; Marcet-Houben, M.; Levin, E.; Sela, N.; Selma-Lázaro, C.; Carmona, L.; Wisniewski, M.; Droby, S.; González-Candelas, L.; Gabaldón, T. Genome, transcriptome, and functional analyses of Penicillium expansum provide new insights into secondary metabolism and pathogenicity. Mol. Plant-Microbe Interact. 2015, 28, 232-248. [CrossRef] [PubMed]

50. McCallum, J.; Tsao, R.; Zhou, T. Factors affecting patulin production by Penicillium expansum. J. Food Prot. 2002, 65, 1937-1942. [CrossRef] [PubMed]

51. Sanzani, S.; Susca, A.; Mastrorosa, S.; Solfrizzo, M. Patulin risk associated with blue mould of pome fruit marketed in southern Italy. Qual. Assur. Saf. Crop. 2017, 9, 23-29. [CrossRef]

52. Judet-Correia, D.; Bollaert, S.; Duquenne, A.; Charpentier, C.; Bensoussan, M.; Dantigny, P. Validation of a predictive model for the growth of Botrytis cinerea and Penicillium expansum on grape berries. Int. J. Food Microbiol. 2010, 142, 106-113. [CrossRef] [PubMed]

53. Tannous, J.; Atoui, A.; El Khoury, A.; Francis, Z.; Oswald, I.P.; Puel, O.; Lteif, R. A study on the physicochemical parameters for Penicillium expansum growth and patulin production: Effect of temperature, pH, and water activity. Food Sci. Nutr. 2016, 4, 611-622. [CrossRef] [PubMed]

54. Zong, Y.; Li, B.; Tian, S. Effects of carbon, nitrogen and ambient $\mathrm{pH}$ on patulin production and related gene expression in Penicillium expansum. Int. J. Food Microbiol. 2015, 206, 102-108. [CrossRef] [PubMed]

55. Snini, S.P.; Tannous, J.; Heuillard, P.; Bailly, S.; Lippi, Y.; Zehraoui, E.; Barreau, C.; Oswald, I.P.; Puel, O. Patulin is a cultivar-dependent aggressiveness factor favouring the colonization of apples by Penicillium expansum. Mol. Plant Pathol. 2016, 17, 920-930. [CrossRef] [PubMed]

56. Janisiewicz, W.J.; Saftner, R.A.; Conway, W.S.; Forsline, P.L. Preliminary evaluation of apple germplasm from Kazakhstan for resistance to postharvest blue mold in fruit caused by Penicillium expansum. HortScience 2008, $43,420-426$.

57. Sun, J.; Janisiewicz, W.J.; Nichols, B.; Jurick, W.M., II; Chen, P. Composition of phenolic compounds in wild apple with multiple resistance mechanisms against postharvest blue mold decay. Postharvest Biol. Technol. 2017, 127, 68-75. [CrossRef]

58. Vilanova, L.; Wisniewski, M.; Norelli, J.; Viñas, I.; Torres, R.; Usall, J.; Phillips, J.; Droby, S.; Teixidó, N. Transcriptomic profiling of apple in response to inoculation with a pathogen (Penicillium expansum) and a non-pathogen (Penicillium digitatum). Plant Mol. Biol. Rep. 2014, 32, 566-583. [CrossRef] 
59. Norelli, J.L.; Wisniewski, M.; Fazio, G.; Burchard, E.; Gutierrez, B.; Levin, E.; Droby, S. Genotypingby-sequencing markers facilitate the identification of quantitative trait loci controlling resistance to Penicillium expansum in Malus sieversii. PLoS ONE 2017, 12, e0172949. [CrossRef] [PubMed]

60. Ballester, A.-R.; Norelli, J.; Burchard, E.; Abdelfattah, A.; Levin, E.; González-Candelas, L.; Droby, S.; Wisniewski, M. Transcriptomic response of resistant (PI613981-Malus sieversii) and susceptible ("Royal Gala") genotypes of apple to blue mold (Penicillium expansum) infection. Front. Plant Sci. 2017, 8. [CrossRef] [PubMed]

61. Janisiewicz, W.J.; Nichols, B.; Bauchan, G.; Chao, T.C.; Jurick, W.M. Wound responses of wild apples suggest multiple resistance mechanism against blue mold decay. Postharvest Biol. Technol. 2016, 117, 132-140. [CrossRef]

62. Wei, J.; Ma, F.; Shi, S.; Qi, X.; Zhu, X.; Yuan, J. Changes and postharvest regulation of activity and gene expression of enzymes related to cell wall degradation in ripening apple fruit. Postharvest Biol. Technol. 2010, 56, 147-154. [CrossRef]

63. Vilanova, L.; Viñas, I.; Torres, R.; Usall, J.; Buron-Moles, G.; Teixidó, N. Increasing maturity reduces wound response and lignification processes against Penicillium expansum (pathogen) and Penicillium digitatum (non-host pathogen) infection in apples. Postharvest Biol. Technol. 2014, 88, 54-60. [CrossRef]

64. Chávez, R.A.S.; Peniche, R.Á.M.; Medrano, S.A.; Muñoz, L.S.; Ortíz, M.d.S.C.; Espasa, N.T.; Sanchis, R.T. Effect of maturity stage, ripening time, harvest year and fruit characteristics on the susceptibility to Penicillium expansum link of apple genotypes from Queretaro, Mexico. Sci. Hortic. 2014, 180, 86-93. [CrossRef]

65. Ahmadi-Afzadi, M.; Tahir, I.; Nybom, H. Impact of harvesting time and fruit firmness on the tolerance to fungal storage diseases in an apple germplasm collection. Postharvest Biol. Technol. 2013, 82, 51-58. [CrossRef]

66. Marin, S.; Morales, H.; Hasan, H.; Ramos, A.; Sanchis, V. Patulin distribution in Fuji and Golden apples contaminated with Penicillium expansum. Food Addit. Contam. 2006, 23, 1316-1322. [CrossRef] [PubMed]

67. Jurick, W.M.; Janisiewicz, W.J.; Saftner, R.A.; Vico, I.; Gaskins, V.L.; Park, E.; Forsline, P.L.; Fazio, G.; Conway, W.S. Identification of wild apple germplasm (Malus spp.) accessions with resistance to the postharvest decay pathogens Penicillium expansum and Colletotrichum acutatum. Plant Breed. 2011, 130, 481-486. [CrossRef]

68. Tahir, I.; Nybom, H.; Ahmadi-Afzadi, M.; Røen, K.; Sehic, J.; Røen, D. Susceptibility to blue mold caused by Penicillium expansum in apple cultivars adapted to a cool climate. Eur. J. Hortic. Sci. 2015, 80, 117-127. [CrossRef]

69. Shao, X.; Tu, K.; Tu, S.; Su, J.; Zhao, Y. Effects of heat treatment on wound healing in Gala and Red fuji apple fruits. J. Agric. Food Chem. 2010, 58, 4303-4309. [CrossRef] [PubMed]

70. Vilanova, L.; Vall-llaura, N.; Torres, R.; Usall, J.; Teixidó, N.; Larrigaudière, C.; Giné-Bordonaba, J. Penicillium expansum (compatible) and Penicillium digitatum (non-host) pathogen infection differentially alter ethylene biosynthesis in apple fruit. Plant Physiol. Biochem. 2017, 120, 132-143. [CrossRef] [PubMed]

71. Ahmadi-Afzadi, M.; Nybom, H.; Ekholm, A.; Tahir, I.; Rumpunen, K. Biochemical contents of apple peel and flesh affect level of partial resistance to blue mold. Postharvest Biol. Technol. 2015, 110, 173-182. [CrossRef]

72. Kumar, D.; Barad, S.; Chen, Y.; Luo, X.; Tannous, J.; Dubey, A.; Glam Matana, N.; Tian, S.; Li, B.; Keller, N. LaeA regulation of secondary metabolism modulates virulence in Penicillium expansum and is mediated by sucrose. Mol. Plant Pathol. 2017, 18, 1150-1163. [CrossRef] [PubMed]

73. Tóth, B.; Kótai, É.; Varga, M.; Pálfi, X.; Baranyi, N.; Szigeti, G.; Kocsubé, S.; Varga, J. Climate change and mycotoxin contamination in Central Europe: An overview of recent findings. Rev. Agric. Rural Dev. 2013, 2, 461-466.

74. Dodd, M.C.; Bouwer, J.J. The supply value chain of fresh produce from field to home: Refrigeration and other supporting technologies. In Postharvest Handling, 3rd ed.; Elsevier: Amsterdam, The Netherlands, 2014; pp. 449-483.

75. Lee, J.; Rudell, D.R.; Davies, P.J.; Watkins, C.B. Metabolic changes in 1-methylcyclopropene (1-MCP)-treated 'Empire'apple fruit during storage. Metabolomics 2012, 8, 742-753. [CrossRef]

76. Gougouli, M.; Koutsoumanis, K.P. Modelling growth of Penicillium expansum and Aspergillus niger at constant and fluctuating temperature conditions. Int. J. Food Microbiol. 2010, 140, 254-262. [CrossRef] [PubMed]

77. Prata, M.B.; Mussatto, S.I.; Rodrigues, L.R.; Teixeira, J.A. Fructooligosaccharide production by Penicillium expansum. Biotechnol. Lett. 2010, 32, 837-840. [CrossRef] [PubMed] 
78. Morales, H.; Marín, S.; Rovira, A.; Ramos, A.; Sanchis, V. Patulin accumulation in apples by Penicillium expansum during postharvest stages. Lett. Appl. Microbiol. 2007, 44, 30-35. [CrossRef] [PubMed]

79. Salomão, B.C.; Aragao, G.M.; Churey, J.J.; Padilla-Zakour, O.I.; Worobo, R.W. Influence of storage temperature and apple variety on patulin production by Penicillium expansum. J. Food Prot. 2009, 72, 1030-1036. [CrossRef] [PubMed]

80. Spadaro, D.; Lorè, A.; Garibaldi, A.; Gullino, M.L. A new strain of Metschnikowia fructicola for postharvest control of Penicillium expansum and patulin accumulation on four cultivars of apple. Postharvest Biol. Technol. 2013, 75, 1-8. [CrossRef]

81. Garcia, D.; Ramos, A.J.; Sanchis, V.; Marín, S. Intraspecific variability of growth and patulin production of 79 Penicillium expansum isolates at two temperatures. Int. J. Food Microbiol. 2011, 151, 195-200. [CrossRef] [PubMed]

82. Lovett, J.; Peeler, J. Effect of $\mathrm{pH}$ on the thermal destruction kinetics of patulin in aqueous solution. J. Food Sci. 1973, 38, 1094-1095. [CrossRef]

83. Welke, J.E.; Hoeltz, M.; Dottori, H.A.; Noll, I.B. Effect of processing stages of apple juice concentrate on patulin levels. Food Control 2009, 20, 48-52. [CrossRef]

84. Janotová, L.; Čížková, H.; Pivoňka, J.; Voldřich, M. Effect of processing of apple puree on patulin content. Food Control 2011, 22, 977-981. [CrossRef]

85. Kingston, C. Maturity indices for apple and pear. Hortic. Rev. 2010, 13, 407-432. [CrossRef]

86. Baert, K.; Devlieghere, F.; Flyps, H.; Oosterlinck, M.; Ahmed, M.M.; Rajković, A.; Verlinden, B.; Nicolaï, B.; Debevere, J.; De Meulenaer, B. Influence of storage conditions of apples on growth and patulin production by Penicillium expansum. Int. J. Food Microbiol. 2007, 119, 170-181. [CrossRef] [PubMed]

87. Li, B.; Lai, T.; Qin, G.; Tian, S. Ambient $\mathrm{pH}$ stress inhibits spore germination of Penicillium expansum by impairing protein synthesis and folding: A proteomic-based study. J. Proteome Res. 2009, 9, 298-307. [CrossRef] [PubMed]

88. Prusky, D.; McEvoy, J.L.; Saftner, R.; Conway, W.S.; Jones, R. Relationship between host acidification and virulence of Penicillium spp. on apple and citrus fruit. Phytopathology 2004, 94, 44-51. [CrossRef] [PubMed]

89. Shao, S.; Zhou, T.; McGarvey, B.D. Comparative metabolomic analysis of Saccharomyces cerevisiae during the degradation of patulin using gas chromatography-mass spectrometry. Appl. Microbiol. Biotechnol. 2012, 94, 789-797. [CrossRef] [PubMed]

90. Desmarchelier, A.; Mujahid, C.; Racault, L.; Perring, L.; Lancova, K. Analysis of patulin in pear-and apple-based foodstuffs by liquid chromatography electrospray ionization tandem mass spectrometry. J. Agric. Food Chem. 2011, 59, 7659-7665. [CrossRef] [PubMed]

91. Li, X.; Li, H.; Li, X.; Zhang, Q. Determination of trace patulin in apple-based food matrices. Food Chem. 2017, 233, 290-301. [CrossRef] [PubMed]

92. Katerere, D.R.; Stockenström, S.; Shephard, G.S. HPLC-DAD method for the determination of patulin in dried apple rings. Food Control 2008, 19, 389-392. [CrossRef]

93. Wibowo, S.; Grauwet, T.; Santiago, J.S.; Tomic, J.; Vervoort, L.; Hendrickx, M.; Van Loey, A. Quality changes of pasteurised orange juice during storage: A kinetic study of specific parameters and their relation to colour instability. Food Chem. 2015, 187, 140-151. [CrossRef] [PubMed]

94. Mohammadi, A.; Tavakoli, R.; Kamankesh, M.; Rashedi, H.; Attaran, A.; Delavar, M. Enzyme-assisted extraction and ionic liquid-based dispersive liquid-liquid microextraction followed by high-performance liquid chromatography for determination of patulin in apple juice and method optimization using central composite design. Anal. Chim. Acta 2013, 804, 104-110. [CrossRef] [PubMed]

95. Sadok, I.; Stachniuk, A.; Staniszewska, M. Developments in the monitoring of patulin in fruits using liquid chromatography: An overview. Food Anal. Methods 2018, 1-18. [CrossRef]

96. Baert, K.; De Meulenaer, B.; Kasase, C.; Huyghebaert, A.; Ooghe, W.; Devlieghere, F. Free and bound patulin in cloudy apple juice. Food Chem. 2007, 100, 1278-1282. [CrossRef]

97. Appell, M.; Dombrink-Kurtzman, M.A.; Kendra, D.F. Comparative study of patulin, ascladiol, and neopatulin by density functional theory. J. Mol. Struct. THEOCHEM 2009, 894, 23-31. [CrossRef]

98. Vaclavikova, M.; Dzuman, Z.; Lacina, O.; Fenclova, M.; Veprikova, Z.; Zachariasova, M.; Hajslova, J. Monitoring survey of patulin in a variety of fruit-based products using a sensitive UHPLC-MS/MS analytical procedure. Food Control 2015, 47, 577-584. [CrossRef] 
99. Brandon, E.; Baars, A.; Biesebeek, J.T.; Oomen, A.; Bakker, M.; De Heer, C. Risk assessment of patulin intake from apple containing products by young children. World Mycotoxin J. 2012, 5, 391-403. [CrossRef]

100. Lu, X.; Zhang, E.; Yin, S.; Fan, L.; Hu, H. Methylseleninic acid prevents patulin-induced hepatotoxicity and nephrotoxicity via the inhibition of oxidative stress and inactivation of p53 and MAPKs. J. Agric. Food Chem. 2017, 65, 5299-5305. [CrossRef] [PubMed]

101. Maidana, L.; Gerez, J.R.; El Khoury, R.; Pinho, F.; Puel, O.; Oswald, I.P.; Bracarense, A.P.F. Effects of patulin and ascladiol on porcine intestinal mucosa: An ex vivo approach. Food Chem. Toxicol. 2016, 98, 189-194. [CrossRef] [PubMed]

102. Assunção, R.; Alvito, P.; Kleiveland, C.; Lea, T. Characterization of in vitro effects of patulin on intestinal epithelial and immune cells. Toxicol. Lett. 2016, 250, 47-56. [CrossRef] [PubMed]

103. Pal, S.; Singh, N.; Ansari, K.M. Toxicological effects of patulin mycotoxin on the mammalian system: An overview. Toxicol. Res. 2017, 6, 764-771. [CrossRef] [PubMed]

104. Puel, O.; Galtier, P.; Oswald, I.P. Biosynthesis and toxicological effects of patulin. Toxins 2010, 2, 613-631. [CrossRef] [PubMed]

105. Tannous, J.; Snini, S.P.; El Khoury, R.; Canlet, C.; Pinton, P.; Lippi, Y.; Alassane-Kpembi, I.; Gauthier, T.; El Khoury, A.; Atoui, A. Patulin transformation products and last intermediates in its biosynthetic pathway, E-and Z-ascladiol, are not toxic to human cells. Arch. Toxicol. 2017, 91, 2455-2467. [CrossRef] [PubMed]

106. Castoria, R.; Mannina, L.; Durán-Patrón, R.; Maffei, F.; Sobolev, A.P.; De Felice, D.V.; Pinedo-Rivilla, C.; Ritieni, A.; Ferracane, R.; Wright, S.A. Conversion of the mycotoxin patulin to the less toxic desoxypatulinic acid by the biocontrol yeast Rhodosporidium kratochvilovae strain LS11. J. Agric. Food Chem. 2011, 59, 11571-11578. [CrossRef] [PubMed]

107. Zhu, R.; Feussner, K.; Wu, T.; Yan, F.; Karlovsky, P.; Zheng, X. Detoxification of mycotoxin patulin by the yeast Rhodosporidium paludigenum. Food Chem. 2015, 179, 1-5. [CrossRef] [PubMed]

108. Hawar, S.; Vevers, W.; Karieb, S.; Ali, B.K.; Billington, R.; Beal, J. Biotransformation of patulin to hydroascladiol by Lactobacillus plantarum. Food Control 2013, 34, 502-508. [CrossRef]

109. Ianiri, G.; Pinedo, C.; Fratianni, A.; Panfili, G.; Castoria, R. Patulin degradation by the biocontrol yeast Sporobolomyces sp. is an inducible process. Toxins 2017, 9, 61. [CrossRef] [PubMed]

110. Fliege, R.; Metzler, M. Electrophilic properties of patulin. N-acetylcysteine and glutathione adducts. Chem. Res. Toxicol. 2000, 13, 373-381. [CrossRef] [PubMed]

111. De Melo, F.T.; de Oliveira, I.M.; Greggio, S.; Dacosta, J.C.; Guecheva, T.N.; Saffi, J.; Henriques, J.A.P.; Rosa, R.M. DNA damage in organs of mice treated acutely with patulin, a known mycotoxin. Food Chem. Toxicol. 2012, 50, 3548-3555. [CrossRef] [PubMed]

112. Pfenning, C.; Esch, H.L.; Fliege, R.; Lehmann, L. The mycotoxin patulin reacts with DNA bases with and without previous conjugation to GSH: Implication for related $\alpha, \beta$-unsaturated carbonyl compounds? Arch. Toxicol. 2016, 90, 433-448. [CrossRef] [PubMed]

113. Schebb, N.H.; Faber, H.; Maul, R.; Heus, F.; Kool, J.; Irth, H.; Karst, U. Analysis of glutathione adducts of patulin by means of liquid chromatography (HPLC) with biochemical detection (BCD) and electrospray ionization tandem mass spectrometry (ESI-MS/MS). Anal. Bioanal. Chem. 2009, 394, 1361-1373. [CrossRef] [PubMed]

114. Mahfoud, R.; Maresca, M.; Garmy, N.; Fantini, J. The mycotoxin patulin alters the barrier function of the intestinal epithelium: Mechanism of action of the toxin and protective effects of glutathione. Toxicol. Appl. Pharmacol. 2002, 181, 209-218. [CrossRef] [PubMed]

115. Guo, C.; Yuan, Y.; Yue, T.; Hatab, S.; Wang, Z. Binding mechanism of patulin to heat-treated yeast cell. Lett. Appl. Microbiol. 2012, 55, 453-459. [CrossRef] [PubMed]

116. Zheng, X.; Yang, Q.; Zhang, H.; Cao, J.; Zhang, X.; Apaliya, M.T. The possible mechanisms involved in degradation of patulin by Pichia caribbica. Toxins 2016, 8, 289. [CrossRef] [PubMed]

117. Iwahashi, Y.; Hosoda, H.; Park, J.-H.; Lee, J.-H.; Suzuki, Y.; Kitagawa, E.; Murata, S.M.; Jwa, N.-S.; Gu, M.-B.; Iwahashi, H. Mechanisms of patulin toxicity under conditions that inhibit yeast growth. J. Agric. Food Chem. 2006, 54, 1936-1942. [CrossRef] [PubMed]

118. Suzuki, T.; Iwahashi, Y. Gene expression profiles of yeast Saccharomyces cerevisiae sod1 caused by patulin toxicity and evaluation of recovery potential of ascorbic acid. J. Agric. Food Chem. 2011, 59, 7145-7154. [CrossRef] [PubMed] 
119. Papp, G.; Horváth, E.; Mike, N.; Gazdag, Z.; Belágyi, J.; Gyöngyi, Z.; Bánfalvi, G.; Hornok, L.; Pesti, M. Regulation of patulin-induced oxidative stress processes in the fission yeast Schizosaccharomyces pombe. Food Chem. Toxicol. 2012, 50, 3792-3798. [CrossRef] [PubMed]

120. Ianiri, G.; Idnurm, A.; Wright, S.A.; Durán-Patrón, R.; Mannina, L.; Ferracane, R.; Ritieni, A.; Castoria, R. Searching for genes responsible for patulin degradation in a biocontrol yeast provides insight into the basis for resistance to this mycotoxin. Appl. Environ. Microbiol. 2013, 79, 3101-3115. [CrossRef] [PubMed]

121. Chen, Y.; Peng, H.-M.; Wang, X.; Li, B.-Q.; Long, M.-Y.; Tian, S.-P. Biodegradation mechanisms of patulin in Candida guilliermondii: An iTRAQ-Based proteomic analysis. Toxins 2017, 9, 48. [CrossRef] [PubMed]

122. Jones, S. Patulin-A Chemical Concern for Apple Producers E Processors; OMAFRA (Ontario Ministry of Agriculture, Food and Rural Affairs): Guelph, ON, Canada, 2016.

123. OMAFRA. Notes on Apple Diseases: Blue Mould and Grey Mould in Stored Apples; OMFRA (Ontario Ministry of Agriculture, Food and Rural Affairs): Guelph, ON, Canada, 2006.

124. Tahir, I.I.; Nybom, H. Tailoring organic apples by cultivar selection, production system, and post-harvest treatment to improve quality and storage life. HortScience 2013, 48, 92-101.

125. Li, H.; Xiao, C. Characterization of fludioxonil-resistant and pyrimethanil-resistant phenotypes of Penicillium expansum from apple. Phytopathology 2008, 98, 427-435. [CrossRef] [PubMed]

126. De Capdeville, G.; Beer, S.V.; Watkins, C.B.; Wilson, C.L.; Tedeschi, L.O.; Aist, J.R. Pre-and post-harvest harpin treatments of apples induce resistance to blue mold. Plant Dis. 2003, 87, 39-44. [CrossRef]

127. Nunes, C.; Usall, J.; Teixido, N.; Eribe, X.O.d.; Vinas, I. Control of post-harvest decay of apples by pre-harvest and post-harvest application of ammonium molybdate. Pest Manag. Sci. 2001, 57, 1093-1099. [CrossRef] [PubMed]

128. Spadoni, A.; Guidarelli, M.; Phillips, J.; Mari, M.; Wisniewski, M. Transcriptional profiling of apple fruit in response to heat treatment: Involvement of a defense response during Penicillium expansum infection. Postharvest Biol. Technol. 2015, 101, 37-48. [CrossRef]

129. Radi, M.; Jouybari, H.A.; Mesbahi, G.; Farahnaky, A.; Amiri, S. Effect of hot acetic acid solutions on postharvest decay caused by Penicillium expansum on Red Delicious apples. Sci. Hortic. 2010, 126, 421-425. [CrossRef]

130. Spadaro, D.; Garibaldi, A.; Gullino, M.L. Control of Penicillium expansum and Botrytis cinerea on apple combining a biocontrol agent with hot water dipping and acibenzolar-S-methyl, baking soda, or ethanol application. Postharvest Biol. Technol. 2004, 33, 141-151. [CrossRef]

131. Zhu, R.; Yu, T.; Guo, S.; Hu, H.; Zheng, X.; Karlovsky, P. Effect of the yeast Rhodosporidium paludigenum on postharvest decay and patulin accumulation in apples and pears. J. Food Prot. 2015, 78, 157-163. [CrossRef] [PubMed]

132. Mahunu, G.K.; Zhang, H.; Apaliya, M.T.; Yang, Q.; Zhang, X.; Zhao, L. Bamboo leaf flavonoid enhances the control effect of Pichia caribbica against Penicillium expansum growth and patulin accumulation in apples. Postharvest Biol. Technol. 2018, 141, 1-7. [CrossRef]

133. Tolaini, V.; Zjalic, S.; Reverberi, M.; Fanelli, C.; Fabbri, A.; Del Fiore, A.; De Rossi, P.; Ricelli, A. Lentinula edodes enhances the biocontrol activity of Cryptococcus laurentii against Penicillium expansum contamination and patulin production in apple fruits. Int. J. Food Microbiol. 2010, 138, 243-249. [CrossRef] [PubMed]

134. Sanzani, S.M.; De Girolamo, A.; Schena, L.; Solfrizzo, M.; Ippolito, A.; Visconti, A. Control of Penicillium expansum and patulin accumulation on apples by quercetin and umbelliferone. Eur. Food Res. Technol. 2009, 228, 381-389. [CrossRef]

135. Zhang, C.; Wang, J.; Zhang, J.; Hou, C.; Wang, G. Effects of $\beta$-aminobutyric acid on control of postharvest blue mould of apple fruit and its possible mechanisms of action. Postharvest Biol. Technol. 2011, 61, 145-151. [CrossRef]

136. Funes, G.J.; Gómez, P.L.; Resnik, S.L.; Alzamora, S.M. Application of pulsed light to patulin reduction in McIlvaine buffer and apple products. Food Control 2013, 30, 405-410. [CrossRef]

137. Avsaroglu, M.; Bozoglu, F.; Alpas, H.; Largeteau, A.; Demazeau, G. Use of pulsed-high hydrostatic pressure treatment to decrease patulin in apple juice. High Press Res. 2015, 35, 214-222. [CrossRef]

138. Hao, H.; Zhou, T.; Koutchma, T.; Wu, F.; Warriner, K. High hydrostatic pressure assisted degradation of patulin in fruit and vegetable juice blends. Food Control 2016, 62, 237-242. [CrossRef] 
139. Zhu, Y.; Koutchma, T.; Warriner, K.; Shao, S.; Zhou, T. Kinetics of patulin degradation in model solution, apple cider and apple juice by ultraviolet radiation. Food Sci. Technol. Int. 2013, 19, 291-303. [CrossRef] [PubMed]

140. Peng, X.; Liu, B.; Chen, W.; Li, X.; Wang, Q.; Meng, X.; Wang, D. Effective biosorption of patulin from apple juice by cross-linked xanthated chitosan resin. Food Control 2016, 63, 140-146. [CrossRef]

141. Tang, H.; Peng, X.; Li, X.; Meng, X.; Liu, B. Biodegradation of mycotoxin patulin in apple juice by calcium carbonate immobilized porcine pancreatic lipase. Food Control 2018, 88, 69-74. [CrossRef]

142. Guo, C.; Yue, T.; Yuan, Y.; Wang, Z.; Guo, Y.; Wang, L.; Li, Z. Biosorption of patulin from apple juice by caustic treated waste cider yeast biomass. Food Control 2013, 32, 99-104. [CrossRef]

143. Silici, S.; Karaman, K. Inhibitory effect of propolis on patulin production of Penicillium expansum in apple juice. J. Food Process. Preserv. 2014, 38, 1129-1134. [CrossRef]

144. Diao, E.; Wang, J.; Li, X.; Wang, X.; Gao, D. Patulin degradation in apple juice using ozone detoxification equipment and its effects on quality. J. Food Process. Preserv. 2018, e13645. [CrossRef]

145. Duan, N.; Bai, Y.; Sun, H.; Wang, N.; Ma, Y.; Li, M.; Wang, X.; Jiao, C.; Legall, N.; Mao, L. Genome re-sequencing reveals the history of apple and supports a two-stage model for fruit enlargement. Nat. Commun. 2017, 8, 249. [CrossRef] [PubMed]

146. Dutot, M.; Nelson, L.; Tyson, R. Predicting the spread of postharvest disease in stored fruit, with application to apples. Postharvest Biol. Technol. 2013, 85, 45-56. [CrossRef]

147. Tahir, I.I.; Johansson, E.; Olsson, M.E. Improving the productivity, quality, and storability of 'Katja'apple by better orchard management procedures. HortScience 2008, 43, 725-729.

148. Chen, Y.; Wen, X.; Sun, Y.; Zhang, J.; Wu, W.; Liao, Y. Mulching practices altered soil bacterial community structure and improved orchard productivity and apple quality after five growing seasons. Sci. Hortic. 2014, 172, 248-257. [CrossRef]

149. Børve, J.; Røen, D.; Stensvand, A. Harvest time influences incidence of storage diseases and fruit quality in organically grown 'Aroma'apples. Eur. J. Hortic. Sci. 2013, 78, 232-238. [CrossRef]

150. Zhang, M.; Xu, L.; Zhang, L.; Guo, Y.; Qi, X.; He, L. Effects of quercetin on postharvest blue mold control in kiwifruit. Sci. Hortic. 2018, 228, 18-25. [CrossRef]

151. Quaglia, M.; Ederli, L.; Pasqualini, S.; Zazzerini, A. Biological control agents and chemical inducers of resistance for postharvest control of Penicillium expansum Link. on apple fruit. Postharvest Biol. Technol. 2011, 59, 307-315. [CrossRef]

152. Morales, H.; Marín, S.; Centelles, X.; Ramos, A.J.; Sanchis, V. Cold and ambient deck storage prior to processing as a critical control point for patulin accumulation. Int. J. Food Microbiol. 2007, 116, 260-265. [CrossRef] [PubMed]

153. Kittemann, D.; McCormick, R.; Neuwald, D.A. Effect of high temperature and 1-MCP application or dynamic controlled atmosphere on energy savings during apple storage. Eur. J. Hortic. Sci. 2015, 80, 33-38. [CrossRef]

154. Wright, A.; Delong, J.; Arul, J.; Prange, R. The trend toward lower oxygen levels during apple (Malus $\times$ domestica Borkh) storage. J. Hortic. Sci. Biotechnol. 2015, 90, 1-13. [CrossRef]

155. Baert, K.; Devlieghere, F.; Amiri, A.; De Meulenaer, B. Evaluation of strategies for reducing patulin contamination of apple juice using a farm to fork risk assessment model. Int. J. Food Microbiol. 2012, 154, 119-129. [CrossRef] [PubMed]

156. De Paiva, E.; Serradilla, M.; Ruiz-Moyano, S.; Córdoba, M.; Villalobos, M.; Casquete, R.; Hernández, A. Combined effect of antagonistic yeast and modified atmosphere to control Penicillium expansum infection in sweet cherries cv. Ambrunés. Int. J. Food Microbiol. 2017, 241, 276-282. [CrossRef] [PubMed]

157. Calvo, H.; Marco, P.; Blanco, D.; Oria, R.; Venturini, M. Potential of a new strain of Bacillus amyloliquefaciens BUZ-14 as a biocontrol agent of postharvest fruit diseases. Food Microbiol. 2017, 63, 101-110. [CrossRef] [PubMed]

158. Jackson, L.S.; Beacham-Bowden, T.; Keller, S.E.; Adhikari, C.; Taylor, K.T.; Chirtel, S.J.; Merker, R.I. Apple quality, storage, and washing treatments affect patulin levels in apple cider. J. Food Prot. 2003, 66, 618-624. [CrossRef] [PubMed]

159. Moss, M.; Long, M. Fate of patulin in the presence of the yeast Saccharomyces cerevisiae. Food Addit. Contam. 2002, 19, 387-399. [CrossRef] [PubMed] 
160. Zhang, H.; Mahunu, G.K.; Castoria, R.; Apaliya, M.T.; Yang, Q. Augmentation of biocontrol agents with physical methods against postharvest diseases of fruits and vegetables. Trends Food Sci. Technol. 2017, 69, 36-45. [CrossRef]

161. Luo, Y.; Zhou, Z.; Yue, T. Synthesis and characterization of nontoxic chitosan-coated $\mathrm{Fe}_{3} \mathrm{O}_{4}$ particles for patulin adsorption in a juice-pH simulation aqueous. Food Chem. 2017, 221, 317-323. [CrossRef] [PubMed]

162. Guo, C.; Guo, M.; Zhang, S.; Qin, D.; Yang, Y.; Li, M. Assessment of patulin adsorption efficacy from aqueous solution by water-insoluble corn flour. J. Food Saf. 2018, 38, e12397. [CrossRef]

163. Ismaiel, A.A.; Bassyouni, R.H.; Kamel, Z.; Gabr, S.M. Detoxification of patulin by Kombucha tea culture. CYTA-J. Food 2016, 14, 271-279. [CrossRef]

164. Basak, S.; Guha, P. Use of predictive model to describe sporicidal and cell viability efficacy of betel leaf (Piper betle L.) essential oil on Aspergillus flavus and Penicillium expansum and its antifungal activity in raw apple juice. LWT-Food Sci. Technol. 2017, 80, 510-516. [CrossRef]

165. Kokkinidou, S.; Floros, J.; LaBorde, L. Kinetics of the thermal degradation of patulin in the presence of ascorbic acid. J. Food Sci. 2014, 79, T108-T114. [CrossRef] [PubMed]

166. Jard, G.; Liboz, T.; Mathieu, F.; Guyonvarc'h, A.; Lebrihi, A. Review of mycotoxin reduction in food and feed: From prevention in the field to detoxification by adsorption or transformation. Food Addit. Contam. Part A 2011, 28, 1590-1609. [CrossRef] [PubMed]

167. Li, W.; Zhou, T.; Wu, T.; Li, X. Saccharomyces cerevisiae YE-7 reduces the risk of apple blue mold disease by inhibiting the fungal incidence and patulin biosynthesis. J. Food Process. Preserv. 2018. [CrossRef]

168. Cao, J.; Zhang, H.; Yang, Q.; Ren, R. Efficacy of Pichia caribbica in controlling blue mold rot and patulin degradation in apples. Int. J. Food Microbiol. 2013, 162, 167-173. [CrossRef] [PubMed]

169. Ricelli, A.; Baruzzi, F.; Solfrizzo, M.; Morea, M.; Fanizzi, F. Biotransformation of patulin by Gluconobacter oxydans. Appl. Environ. Microbiol. 2007, 73, 785-792. [CrossRef] [PubMed]

170. Wallace, R.L.; Hirkala, D.L.; Nelson, L.M. Postharvest biological control of blue mold of apple by Pseudomonas fluorescens during commercial storage and potential modes of action. Postharvest Biol. Technol. 2017, 133, 1-11. [CrossRef]

171. Wang, L.; Yue, T.; Yuan, Y.; Wang, Z.; Ye, M.; Cai, R. A new insight into the adsorption mechanism of patulin by the heat-inactive lactic acid bacteria cells. Food Control 2015, 50, 104-110. [CrossRef]

172. Ammar, H.A.; Awny, N.M.; Fahmy, H.M. Influence of environmental conditions of atoxigenic Aspergillus flavusHFB1 on biocontrol of patulin produced by a novel apple contaminant isolate, A. terreusHAP1, in vivo and in vitro. Biocatal. Agric. Biotechnol. 2017, 12, 36-44. [CrossRef]

173. Dong, X.; Jiang, W.; Li, C.; Ma, N.; Xu, Y.; Meng, X. Patulin biodegradation by marine yeast Kodameae ohmeri. Food Addit. Contam. Part A 2015, 32, 352-360. [CrossRef]

174. Wang, Y.; Yuan, Y.; Liu, B.; Zhang, Z.; Yue, T. Biocontrol activity and patulin-removal effects of Bacillus subtilis, Rhodobacter sphaeroides and Agrobacterium tumefaciens against Penicillium expansum. J. Appl. Microbiol. 2016, 121, 1384-1393. [CrossRef] [PubMed]

175. Topcu, A.; Bulat, T.; Wishah, R.; Boyac1, I.H. Detoxification of aflatoxin B1 and patulin by Enterococcus faecium strains. Int. J. Food Microbiol. 2010, 139, 202-205. [CrossRef] [PubMed]

176. Yu, T.; Li, H.Y.; Zheng, X.D. Synergistic effect of chitosan and Cryptococcus laurentii on inhibition of Penicillium expansum infections. Int. J. Food Microbiol. 2007, 114, 261-266. [CrossRef] [PubMed]

177. Yang, Q.; Zhang, H.; Zhang, X.; Zheng, X.; Qian, J. Phytic acid enhances biocontrol activity of Rhodotorula mucilaginosa against Penicillium expansum contamination and patulin production in apples. Front. Microbiol. 2015, 6, 1296. [CrossRef] [PubMed]

(C) 2018 by the authors. Licensee MDPI, Basel, Switzerland. This article is an open access article distributed under the terms and conditions of the Creative Commons Attribution (CC BY) license (http://creativecommons.org/licenses/by/4.0/). 